\title{
Selective oxidation of glycerol in a base-free aqueous solution: A short review
}

\author{
Lihua Yang a, Xuewen Li a , Ping Chen a, Zhaoyin Hou a,b,* \\ a Key Laboratory of Biomass Chemical Engineering of Ministry of Education, Department of Chemistry, Zhejiang University, Hangzhou 310028, Zhejiang, \\ China \\ b Center of Chemistry for Frontier Technologies, Department of Chemistry, Zhejiang University, Hangzhou 310028, Zhejiang, China
}

\section{A R T I C L E I N F 0}

\section{Article history:}

Received 18 November 2018

Accepted 9 January 2019

Published 5 July 2019

\section{Keywords:}

Glycerol

Oxidation

Base-free condition

Catalyst

Reaction mechanism

\begin{abstract}
A B S T R A C T
Catalytic transformation of glycerol to value-added products has attracted the attention of scientists all over the world. Among various transformations, selective oxidation of glycerol with molecular oxygen to dihydroxyacetone, glyceric acid, glyceraldehydes, and tartronic acid is challenging both from the viewpoint of academic research and industrial application. Herein, we review the recent progresses in the selective oxidation of glycerol under base-free conditions. Those catalysts widely reported for the selective oxidation of the terminal hydroxyl and secondary hydroxyl groups in glycerol, such as monometallic Au, Pt, and Pd NPs, and bimetallic Au-Pt, Au-Pd, Pt-Bi, Pt-Sb, and $\mathrm{Pt}-\mathrm{Cu}$, were compared and discussed in detail. The reaction mechanism over Pt-based catalysts, possible catalyst deactivation, and the corresponding improvements are presented. Further, the recent progresses in the continuous oxidation of glycerol in fixed bed reactors and its excellent selectivity in the formation of dihydroxyacetone are highlighted.
\end{abstract}

(C) 2019, Dalian Institute of Chemical Physics, Chinese Academy of Sciences. Published by Elsevier B.V. All rights reserved.

\section{Introduction}

Biodiesel, a well-known alternative fuel for diesel engines [1-5], can be produced from renewable biological sources such as vegetable oils by transesterification (Fig. 1). It has the advantages of renewability and clean-burning ability, and can be used as an alternative for diesel. Compared to the conventional fossil diesel fuel exhausts, the biodiesel exhaust can have reduced hydrocarbons, particulate matters, and CO [6]. According to the statistics and analysis of the Department of Energy, the production of biodiesel in the United States alone reached 1.2 billion gallons in 2015 [7], and it is even forecasted to be nearly 12 billion gallon in 2020, owing to an average growth rate of $42 \%$ per year [8]. Glycerol, a side-product produced in a large surplus during the production of biodiesel via transesterification (Fig. 1) $[9,10]$ has been driving investigations to find new applications of this highly versatile compound [1,11-14].

The production of glycerol reached 3.5 Mt/year in 2015 [15], and the quantity of glycerol produced is predicted to be six times more than the demand by the year 2020 [16,17]. Currently, glycerol is widely used in the production of food additives, cosmetics, and personal care products, as well as in various industrial applications such as the synthesis of nitroglycerin, alkyd resin, and epoxy resin, production of detergents, cellophane, triacetin, tobacco, and explosives $[12,18]$. However, raw glycerol from biodiesel production is avoided in these sectors because of its poor quality. Catalytic conversion of the biodiesel-based glycerol into value-added products (especially,

\footnotetext{
* Corresponding author. Tel/Fax: +86-571-88273283; E-mail: zyhou@zju.edu.cn

This work was supported by the National Natural Science Foundation of China $(21773208,21473155)$ and the Natural Science Foundation of Zhejiang Province (L12B03001).

DOI: S1872-2067(19)63301-2 | http://www.sciencedirect.com/science/journal/18722067 | Chin. J. Catal., Vol. 40, No. 7, July 2019
} 


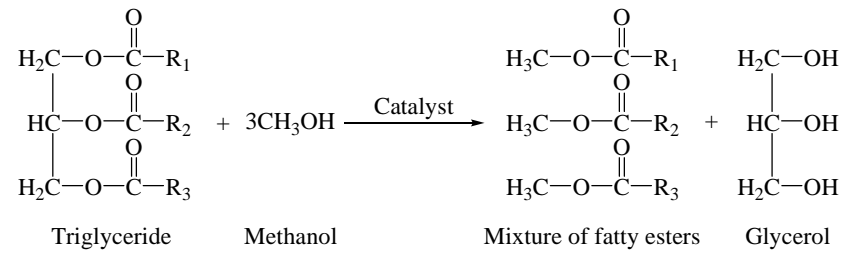

Fig. 1. Transesterification of triglycerides with methanol.

valuable $\mathrm{C}_{3}$ molecules) is promising and interesting from the view-point of industrial application [12].

\section{Catalytic conversion of glycerol into valuable chemicals}

Glycerol is a highly functionalized molecule with three hy- droxyl groups. It can be converted into a series of important chemicals via oxidation [19-23], hydrogenolysis [24-29], dehydration [30-32], esterification [33], oxidative carbonylation [34], transesterification [35,36], and polymerization [37,38], and these reactions have been well-summarized in a previous review (Fig. 2) [1].

Some important $\mathrm{C}_{3}$ oxygenated chemicals, such as dihydroxyacetone (DHA), glyceraldehyde (GLYHD), glyceric acid (GLYA), tartronic acid (TARAC), hydroxypyruic acid (HPYA), mesoxalic acid, and hydroxymethyl glyoxal, can be obtained by the selective oxidation of glycerol. The main progresses and achievements in the selective oxidation of glycerol have been well-summarized by Pagliaro et al. in 2007 [39], Ide et al. in 2014 [40], Villa et al. in 2015 [41], and Dodekatos et al. in 2018 [42].

At the same time, several commodity chemicals such as

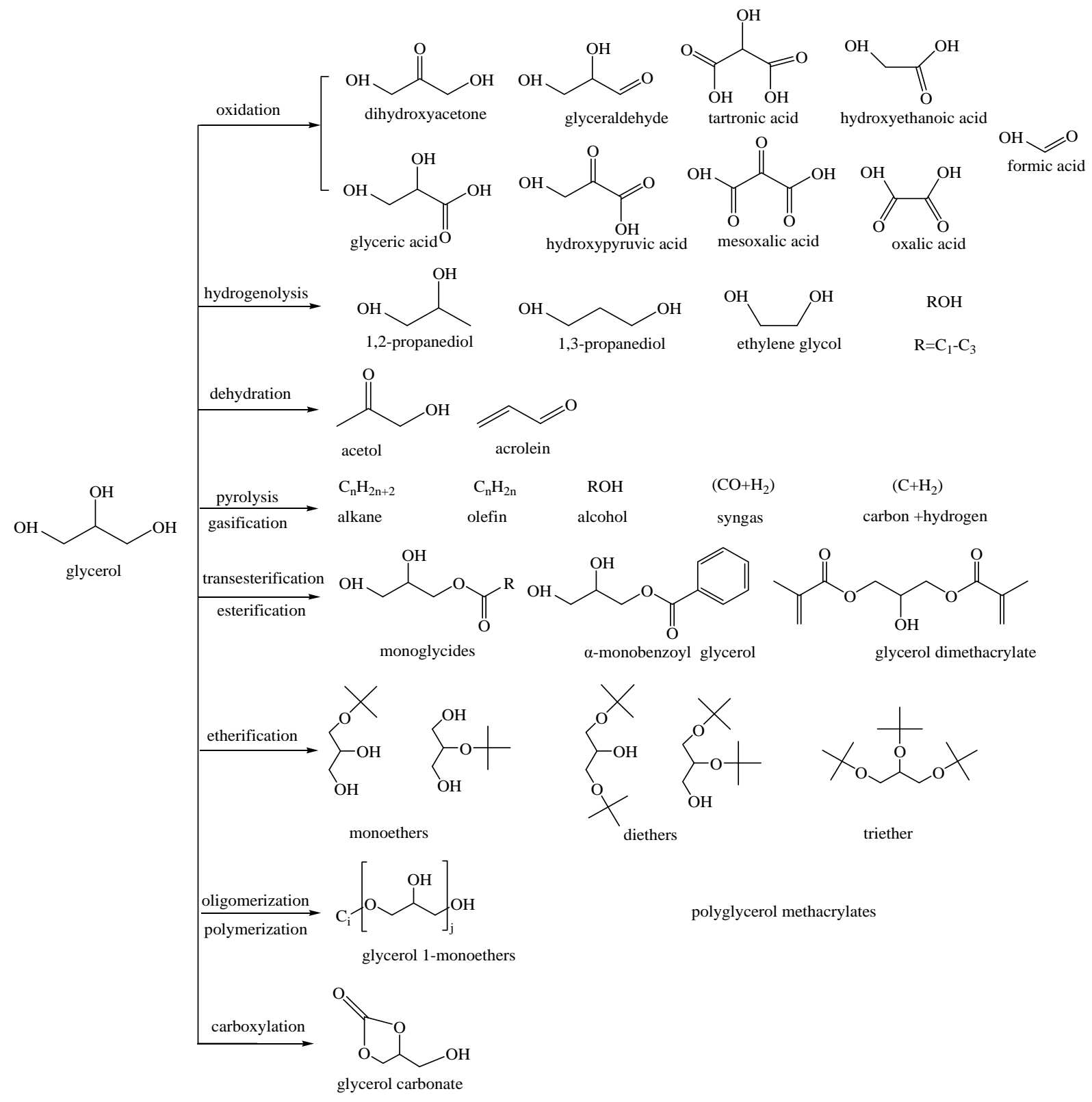

Fig. 2. Catalytic processes and products that can be obtained from glycerol. Reprinted with permission from [1], Copyright (2008) RSC. 
propanediols and acrolein could be produced via the hydrogenolysis and dehydration of glycerol. Further, recent progress in the hydrogenolysis of glycerol has been reviewed by Tomishige et al. in 2011 [43], Guo et al. in 2015 [44], and Ueda et al. in 2016 [45]. The progress in the dehydration of glycerol has been reviewed by Katryniok et al. in 2013 [46].

Other chemicals such as alkane, olefin, alcohol, and syngas can also be prepared via the pyrolysis and gasification of glycerol. Transesterification of glycerol to food additives [47], esterification of glycerol to fuel additives [48], oligomerization of glycerol to biodegradable surfactants [49-51], and carboxylation of glycerol to glycerol carbonate $[35,52]$ have also attracted the attention of several groups over the past few years.

Among the reported catalytic reactions, selective oxidation of glycerol to $\mathrm{C}_{3}$ oxygenated chemicals with molecular oxygen over a heterogeneous catalyst has attracted much attention both from the viewpoint of academic research and industrial applications. In the past decade, a series of $\mathrm{Pt}, \mathrm{Pt}-\mathrm{Bi}, \mathrm{Pt}-\mathrm{Cu}$, $\mathrm{Pt}-\mathrm{Sb}$, and Pt-Co catalysts on the surface of active carbon, multiwalled carbon nanotubes (MWCNTs), carbon nanofibers, graphene, and $\mathrm{N}$-doped carbon supports were prepared and tested in the selective oxidation of glycerol in our laboratory. Herein, we review the recent progresses in the selective oxidation of glycerol in a base-free aqueous solution, using heterogeneous catalysts.

\section{Selective oxidation of glycerol to $C_{3}$ oxygenated chemicals}

Since 2000, a large number of papers have been published on the catalytic conversion of glycerol. Among those, selective oxidation of glycerol to valuable oxygenated derivatives, such as GLYA, DHA, HPYA, and TARAC (Fig. 3), has been a popular subject. This might be because these important oxygenated derivatives are currently prepared using stoichiometric quantities of costly and polluting oxidants (e.g., potassium permanganate, nitric acid, or chromic acid) and/or fermentation processes with low productivity [53-66].

In 1993, the pioneering work on the catalytic oxidation of glycerol over a commercial solid Pt/C catalyst was disclosed by Kimura et al. [53]. GLYA, the oxidation product of the terminal hydroxyl in glycerol, was found to be the main product, and the detected selectivity of GLYA reached $19.4 \%$ at $37 \%$ conversion of glycerol at $323 \mathrm{~K}, \mathrm{pH}=2-4$, and glycerol $/ \mathrm{Pt}=842.4$. Howev$\mathrm{er}$, the conversion of glycerol was quite low in the absence of an added alkali. After that, the selective oxidation of glycerol under varied reaction conditions (with the solution $\mathrm{pH}$ ranging from 2 to 11) was performed over a series of $\mathrm{Pt} / \mathrm{C}$ and $\mathrm{Pd} / \mathrm{C}$ catalysts by Besson et al. [54]. They found that the GLYA selectivity increased from $55 \%$ (on $\mathrm{Pt} / \mathrm{C}$, at $\mathrm{pH}=7$ ) to $70 \%$ (on $\mathrm{Pd} / \mathrm{C}$, at $\mathrm{pH}$ $=11$ ) with an increase in basicity of the reaction medium.

Since 2000, a series of Au-based catalysts were reported for the oxidation of glycerol by Hutchings [55-57], Prati [58,59], Davis [60], Claus [61], and Xu et al. [67,68]. It can be concluded that $\mathrm{Au}$ nanoparticles sized between 15 and $30 \mathrm{~nm}$ exhibited a higher selectivity to GLYA at a moderate glycerol conversion, whereas bigger Au particles (>50 nm) were inactive even in a strong basic solution [55-57]. In the basic solution (molar ratio of $\mathrm{NaOH} /$ glycerol $=4$ ), even the well-dispersed Au nanoparticles (NPs) on carbon with a mean diameter centered at $6 \mathrm{~nm}$ could not maintain the initially observed selectivity at full conversion [58,59]. More accurately, it was found that $5 \mathrm{~nm} \mathrm{Au}$ particles were more active (at $\mathrm{pH}=13.8$ ) [60] and traditional oxides-supported (on supports such as $\mathrm{TiO}_{2}, \mathrm{MgO}$, and $\mathrm{Al}_{2} \mathrm{O}_{3}$ ) $\mathrm{Au}$ NPs were more favorable than $\mathrm{Au} / \mathrm{carbon}$ for the oxidation of glycerol in a basic solution [61].

Aforementioned studies over supported Au catalysts also indicated that Au NPs alone were inactive without the help of base [56]. Several researchers disclosed that the added base can abstract $\mathrm{H}$ from terminal hydroxyl group in glycerol and activate the oxidation reaction [54,56]. However, the added base would neutralize the produced free acids and organic salts are mainly formed in the reaction mixture. At the same time, base additives can promote the cleavage of $\mathrm{C}-\mathrm{C}$ bond, leading to the formation of undesired $\mathrm{C}_{1}$ by-products, e.g., $\mathrm{CO}_{2}, \mathrm{HCHO}$, and $\mathrm{HCOOH}$ [56]. Those typical catalysts and results from previous studies in the catalytic oxidation of glycerol are summarized in Table 1.

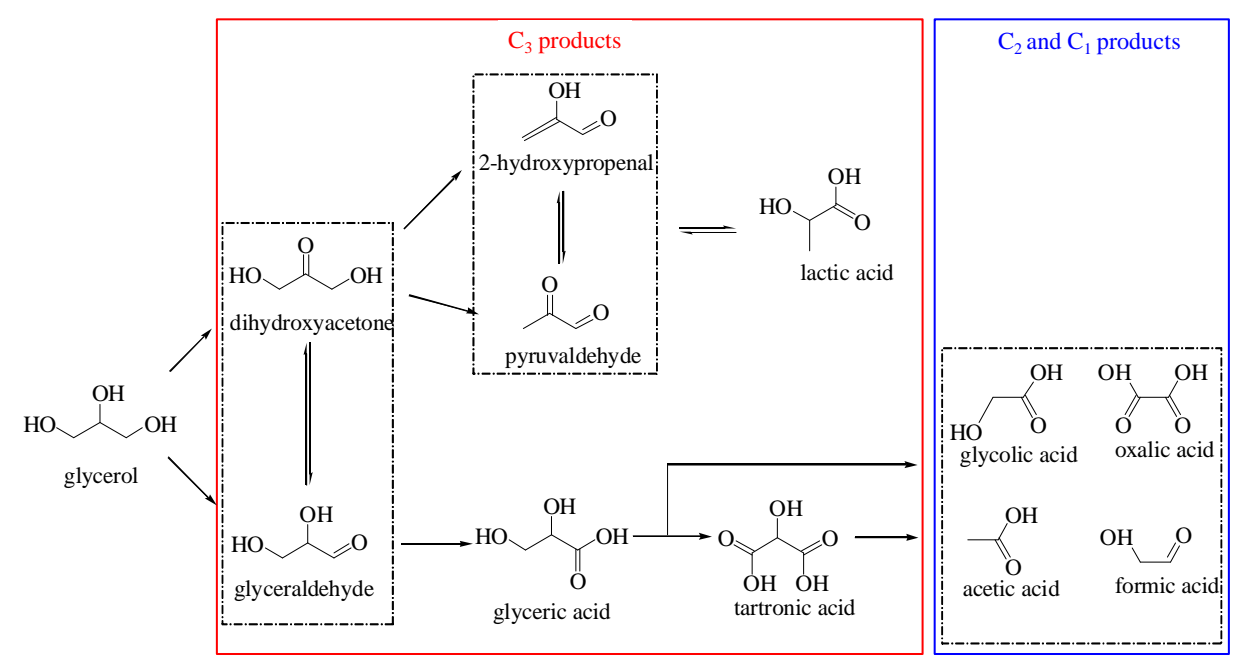

Fig. 3. Reaction scheme for glycerol oxidation. Reprinted with permission from [23], Copyright (2018) John Wiley and Sons. 
Table 1

Typical catalysts used for the oxidation of glycerol.

\begin{tabular}{|c|c|c|c|c|}
\hline Catalyst & Reaction conditions & $\begin{array}{l}\text { Conv. }{ }^{a}(\%) \\
\text { or TOF }\left(\mathrm{h}^{-1}\right)\end{array}$ & $\begin{array}{l}\text { Selectivity and } \\
\text { yield }{ }^{\mathrm{b}}(\%)\end{array}$ & Ref. \\
\hline $\mathrm{Pt} / \mathrm{charcoal}$ & $10 \%$ GLY, $323 \mathrm{~K}, \mathrm{pH} 2-4$, air (0.1 MPa), $4 \mathrm{~h}$ & 37 & $19.4\left(Y_{\mathrm{GLYA}}\right), 4\left(Y_{\mathrm{DHA}}\right)$ & [53] \\
\hline $5 \% \mathrm{Pt} / \mathrm{C}$ & $10 \% \mathrm{GLY}, 333 \mathrm{~K}, \mathrm{pH}=7,5 \mathrm{~h}$ & 90 & $55\left(S_{\mathrm{GLYA}}\right)$ & [54] \\
\hline $5 \% \mathrm{Pd} / \mathrm{C}$ & $10 \% \mathrm{GLY}, 333 \mathrm{~K}, 30 \% \mathrm{NaOH}(\mathrm{pH}=11), 5 \mathrm{~h}$ & 100 & $8\left(S_{\mathrm{DHA}}\right), 70\left(S_{\mathrm{GLYA}}\right)$ & [54] \\
\hline 5Pt/MWNTs & GLY solution $(0.1 \mathrm{~g} / \mathrm{mL}, 50 \mathrm{~mL}), 0.5 \mathrm{~g}$ catalyst, $333 \mathrm{~K}, \mathrm{O}_{2} 150 \mathrm{~mL} / \mathrm{min}, 6 \mathrm{~h}$ & 70.1 & $69.8\left(S_{\mathrm{GLYA}}\right)$ & [69] \\
\hline $\mathrm{Pt} / \mathrm{H}_{2} \mathrm{O}_{2}-\mathrm{C}$ & GLY solution $(0.1 \mathrm{~g} / \mathrm{mL}, 50 \mathrm{~mL})$, catalyst $0.5 \mathrm{~g}, 333 \mathrm{~K}$, oxygen $150 \mathrm{~mL} / \mathrm{min}, 6 \mathrm{~h}$ & 50 & $47.4\left(S_{\mathrm{GLYA}}\right)$ & [70] \\
\hline 5Pt/S-MWNTs & $\begin{array}{l}\text { GLY solution }(0.1 \mathrm{~g} / \mathrm{mL}, 50 \mathrm{~mL}), 0.5 \mathrm{~g} \text { catalyst, GLY/Pt ratio } 445,333 \mathrm{~K} \\
\qquad \mathrm{O}_{2} 150 \mathrm{~mL} / \mathrm{min}, 6 \mathrm{~h}\end{array}$ & 90.4 & $68.3\left(S_{\mathrm{GLYA}}\right)$ & [72] \\
\hline $\mathrm{Pt} / \mathrm{S}-\mathrm{CNFs}$ & Catalyst $0.5 \mathrm{~g}$, GLY solution $(0.1 \mathrm{~g} / \mathrm{mL}, 50 \mathrm{~mL}), 333 \mathrm{~K}, 0.4 \mathrm{MPa} \mathrm{O}_{2}+1.6 \mathrm{MPa} \mathrm{N}_{2}, 6 \mathrm{~h}$ & 89.9 & $83.2\left(S_{\mathrm{GLYA}}\right)$ & [73] \\
\hline $5.0 \% \mathrm{Pt} / \mathrm{CNTs}$ & GLY solution $(0.1 \mathrm{~g} / \mathrm{mL}, 30 \mathrm{~mL}), \mathrm{GLY} / \mathrm{Pt}$ molar ratio $890,333 \mathrm{~K}, \mathrm{O}_{2} 150 \mathrm{~mL} / \mathrm{min}, 6 \mathrm{~h}$ & 63.0 & $\begin{array}{c}37.6\left(S_{\mathrm{GLYA}}\right) \\
36.2\left(S_{\mathrm{GLYHD}}\right)\end{array}$ & [74] \\
\hline $\mathrm{Pt} / \mathrm{K}-\mathrm{AMC}$ & $\begin{array}{l}\text { GLY solution }(0.1 \mathrm{~mol} / \mathrm{L}, 25 \mathrm{~mL}), 0.1 \mathrm{~g} \text { catalyst, GLY } / \text { metal }=250,298 \mathrm{~K} \text {, } \\
\mathrm{O}_{2} 20 \mathrm{~mL} / \mathrm{min}, 8 \mathrm{~h}\end{array}$ & 67.6 & $78.3\left(S_{\mathrm{GLYA}}\right)$ & [76] \\
\hline 1\% Pt/CNTs & $\begin{array}{l}\text { GLY solution }(0.1 \mathrm{~mol} / \mathrm{L}, 10 \mathrm{~mL} \text { ), } 0.039 \mathrm{~g} \text { catalyst, GLY/Pt } 500 \text { (molar ratio), } 333 \mathrm{~K} \text {, } \\
\qquad \mathrm{O}_{2} 0.1 \mathrm{MPa}, \mathrm{O}_{2} 10 \mathrm{~mL} / \mathrm{min}, 4 \mathrm{~h}\end{array}$ & 51.5 & $43.2\left(S_{\mathrm{GLYA}}\right)$ & [79] \\
\hline $1 \% \mathrm{Pt} / \mathrm{N}-\mathrm{CNTs}$ & $\begin{array}{l}\text { GLY solution }(0.1 \mathrm{~mol} / \mathrm{L}, 10 \mathrm{~mL} \text { ), } 0.039 \mathrm{~g} \text { catalyst, GLY/Pt } 500 \text { (molar ratio), } 333 \mathrm{~K} \text {, } \\
\qquad \mathrm{O}_{2} 0.1 \mathrm{MPa}, \mathrm{O}_{2} 10 \mathrm{~mL} / \mathrm{min}, 4 \mathrm{~h}\end{array}$ & 76.1 & $55.6\left(S_{\mathrm{GLYA}}\right)$ & [79] \\
\hline $\mathrm{Pt} / \mathrm{MCN}-5$ & 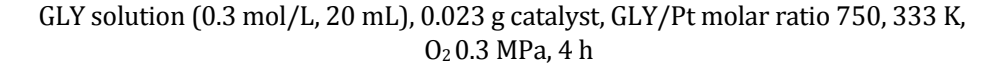 & 63.1 & $\begin{array}{l}58.5\left(S_{\mathrm{GLYA}}\right) 24.3 \\
\quad\left(S_{\mathrm{GLYHD}}\right)\end{array}$ & [82] \\
\hline Pt/N-MWCNTs & GLY solution $(0.1 \mathrm{~g} / \mathrm{mL}, 10 \mathrm{~mL})$, catalyst $0.1 \mathrm{~g}, 333 \mathrm{~K}, 0.5 \mathrm{MPa} \mathrm{O}_{2}, 3 \mathrm{~h}$ & 54.9 & $83\left(S_{\text {GLYA }}\right)$ & [84] \\
\hline $\mathrm{Pt}_{2.5} / \mathrm{N}-\mathrm{XC}-72$ & GLY solution $(0.1 \mathrm{~g} / \mathrm{mL}, 5 \mathrm{~mL})$, catalyst $0.025 \mathrm{~g}, 333 \mathrm{~K}, 0.6 \mathrm{MPa} \mathrm{O}_{2}, 3 \mathrm{~h}$ & 66.6 & $73.8\left(S_{\mathrm{GLYA}}\right)$ & [85] \\
\hline Pt/NG-MWCNTs & GLY solution $(0.1 \mathrm{~g} / \mathrm{mL}, 10 \mathrm{~mL})$, catalyst $0.1 \mathrm{~g}, 333 \mathrm{~K}, 0.5 \mathrm{MPa}_{2}, 3 \mathrm{~h}$ & 64.4 & $81.0\left(S_{\mathrm{GLYA}}\right)$ & [86] \\
\hline $\begin{array}{l}\text { AuPt }(6: 4) / \\
\text { H-mordenite }\end{array}$ & $\begin{array}{l}\text { GLY solution }(0.3 \mathrm{~mol} / \mathrm{L}), 0.3 \mathrm{MPa} \mathrm{O}_{2}, 1250 \mathrm{rpm}, \mathrm{GLY} / \mathrm{metal}=500(\mathrm{~mol} / \mathrm{mol}) \text {, } \\
373 \mathrm{~K}, 2 \mathrm{~h}\end{array}$ & 70 & $83\left(S_{\mathrm{GLYA}}\right)$ & [89] \\
\hline $\operatorname{AuPt}(1: 3) / \mathrm{MgO}$ & Mole fraction of GLY $/$ metal $=500,0_{2} 300 \mathrm{kPa}, 296 \mathrm{~K}, 24 \mathrm{~h}$ & 42.5 & & [92] \\
\hline $\mathrm{Pt}_{60} \mathrm{Au}_{40}$-starch/HT & GLY $0.5 \mathrm{mmol}, \mathrm{H}_{2} \mathrm{O} 2 \mathrm{~mL}$, catalyst $20 \mathrm{mg}$, GLY $/$ metal = 287, & 73 & & [93] \\
\hline $5 \mathrm{Pt} / \mathrm{C}$ & Catalyst $0.5 \mathrm{~g}$, GLY solution $(0.1 \mathrm{~g} / \mathrm{mL}, 50 \mathrm{~mL}), 3$ & 70.3 & & [95] \\
\hline 3Pt-Cu/C & Catalyst $0.5 \mathrm{~g}$, GLY solution $(0.1 \mathrm{~g} / \mathrm{mL}, 50 \mathrm{~mL}), 333 \mathrm{~K}, \mathrm{O}_{2} 150 \mathrm{~mL} / \mathrm{min}, 6 \mathrm{~h}$ & 81.6 & $\begin{array}{l}67.0\left(S_{\mathrm{GLYA}}\right) \\
54.6\left(Y_{\mathrm{GLYA}}\right)\end{array}$ & [95] \\
\hline $5 \mathrm{Pt}-\mathrm{Cu} / \mathrm{C}$ & Catalyst $0.5 \mathrm{~g}$, GLY solution $(0.1 \mathrm{~g} / \mathrm{mL}, 50 \mathrm{~mL}), 333 \mathrm{~K}, \mathrm{O}_{2} 150 \mathrm{~mL} / \mathrm{min}, 6 \mathrm{~h}$ & 86.2 & $\begin{array}{l}70.8\left(S_{\mathrm{GLYA}}\right) \\
61\left(Y_{\mathrm{GLYA}}\right)\end{array}$ & [95] \\
\hline PtCo/RGO & Catalyst $25 \mathrm{mg}$, GLY solution $(0.1 \mathrm{~g} / \mathrm{mL}, 5 \mathrm{~mL}), 333 \mathrm{~K}, \mathrm{O}_{2} 30 \mathrm{~mL} / \mathrm{min}, 3 \mathrm{~h}$ & 70.2 & $85.9\left(S_{\mathrm{GLYA}}\right)$ & [96] \\
\hline $\mathrm{Pt}_{9} \mathrm{Sn}_{1} / \mathrm{C}-\mathrm{R}$ & GLY $5 \mathrm{mmol}, \mathrm{H}_{2} \mathrm{O} 10 \mathrm{~mL}$, catalyst $50 \mathrm{mg}$, GLY $/$ metal $=1000, \mathrm{O}_{2} 15 \mathrm{~mL} / \mathrm{min}, 333 \mathrm{~K}, 2 \mathrm{~h}$ & 43.1 & $\begin{array}{l}46.0\left(S_{\mathrm{GLYA}}\right) \\
23.9\left(S_{\mathrm{GLYHD}}\right)\end{array}$ & [97] \\
\hline $\mathrm{Pd}-\mathrm{Pt} / \mathrm{TiO}_{2}$ & $373 \mathrm{~K}$, substrate $/$ metal ratio $=2728: 1,0.5 \mathrm{~h}$ & $210 \mathrm{~h}^{-1}$ & $\begin{array}{l}60.5\left(S_{\mathrm{GLYA}}\right) \\
37.1\left(S_{\mathrm{DHA}}\right)\end{array}$ & [98] \\
\hline $\mathrm{Au}-\mathrm{Pd}-\mathrm{Pt} / \mathrm{TiO}_{2}$ & $373 \mathrm{~K}$, substrate:metal ratio $=2728: 1,0.5 \mathrm{~h}$ & $378 \mathrm{~h}^{-1}$ & $\begin{array}{l}55.1\left(S_{\mathrm{GLYA}}\right) \\
39.4\left(S_{\mathrm{DHA}}\right)\end{array}$ & [98] \\
\hline $\mathrm{AuPt} / \mathrm{NiO}$ & GLY solution $(0.3 \mathrm{~mol} / \mathrm{L}), \mathrm{GLY} / \mathrm{metal}=500 \mathrm{~mol} / \mathrm{mol}, \mathrm{O}_{2} 0.3 \mathrm{MPa}, 353 \mathrm{~K}$ & $283 h^{-1 c}$ & $\begin{array}{c}51\left(S_{\mathrm{GLYA}}\right) \\
10\left(S_{\mathrm{GLYHD}}\right)\end{array}$ & [99] \\
\hline Au-Pt/HT (1:3) & $\begin{array}{l}\text { GLY solution }(0.3 \mathrm{~mol} / \mathrm{L}, 15 \mathrm{~mL}) \text {, GLY } / \text { metal mole fraction }=1000,0_{2} 300 \mathrm{kPa} \text {, } \\
\qquad 333 \mathrm{~K}, 4 \mathrm{~h}\end{array}$ & 57 & $72\left(S_{\mathrm{GLYA}}\right)$ & [100] \\
\hline $\begin{array}{l}\mathrm{Au}-\mathrm{Pt} / \\
(\mathrm{MgCO} \\
3)_{4} \mathrm{Mg}(\mathrm{OH})_{2}\end{array}$ & $\begin{array}{l}\text { GLY solution }(0.3 \mathrm{~mol} / \mathrm{L}, 15 \mathrm{~mL}) \text {, GLY } / \text { metal mole fraction }=1000,0_{2} 300 \mathrm{kPa} \text {, } \\
\qquad 333 \mathrm{~K}, 4 \mathrm{~h}\end{array}$ & 50 & $69\left(S_{\mathrm{GLYA}}\right)$ & [100] \\
\hline $\mathrm{Au}-\mathrm{Pt} / \mathrm{MgO}$ & $\begin{array}{l}\text { GLY solution }(0.3 \mathrm{~mol} / \mathrm{L}, 15 \mathrm{~mL}), \mathrm{GLY} / \text { metal mole fraction }=1000, \mathrm{O}_{2} 300 \mathrm{kPa} \text {, } \\
333 \mathrm{~K}, 4 \mathrm{~h}\end{array}$ & 45 & $40\left(S_{\mathrm{GLYA}}\right)$ & [100] \\
\hline Bi-Pt charcoal & pH 2-4, 10\% GLY, air $0.1 \mathrm{MPa}, 323 \mathrm{~K}, 4 \mathrm{~h}$, using a batch reactor & 30 & $20\left(Y_{\mathrm{DHA}}\right)$ & $\begin{array}{c}{[53,1} \\
02]\end{array}$ \\
\hline $\begin{array}{l}0.6 \% \mathrm{Bi}-3 \% \mathrm{Pt} / \\
\text { granular charcoal }\end{array}$ & $50 \% \mathrm{GLY}, 323 \mathrm{~K}, \mathrm{O}_{2} / \mathrm{GLY}=2(\mathrm{~mol} / \mathrm{mol})$, using a fixed-bed catalytic reactor & 40 & $30\left(Y_{\mathrm{DHA}}\right)$ & $\begin{array}{c}{[53,1} \\
02]\end{array}$ \\
\hline $\mathrm{Bi}-\mathrm{Pt} / \mathrm{C}$ & 10\% GLY, air 0.1 MPa, 333 K, 5 h, pH 2. & 75 & $37\left(Y_{\mathrm{DHA}}\right)$ & {$[54]$} \\
\hline $\mathrm{Pt} / \mathrm{C}$ & Catalyst $0.5 \mathrm{~g}$, GLY solution $(0.1 \mathrm{~g} / \mathrm{mL}, 50 \mathrm{~mL}), 333 \mathrm{~K}, \mathrm{O}_{2} 150 \mathrm{~mL} / \mathrm{min}, 6 \mathrm{~h}$ & 70.3 & $9.2\left(\right.$ DHA $_{\mathrm{DH}}$ & [112] \\
\hline $5 \% \mathrm{Pt}-5 \% \mathrm{Bi} / \mathrm{C}$ & Catalyst $0.5 \mathrm{~g}$, GLY solution $(0.1 \mathrm{~g} / \mathrm{mL}, 50 \mathrm{~mL}), 333 \mathrm{~K}, \mathrm{O}_{2} 150 \mathrm{~mL} / \mathrm{min}, 6 \mathrm{~h}$ & 91.5 & $49\left(S_{\text {DHA }}\right)$ & [112] \\
\hline Pt/NCNT & $\begin{array}{l}50 \mathrm{~g} \text { of } 10 \mathrm{wt} . \% \mathrm{GLY} \text { aqueous solution, } 0.1 \mathrm{~g} \text { catalyst, } 333 \mathrm{~K}, \mathrm{O}_{2} 150 \mathrm{~mL} / \mathrm{min}, 600 \\
\mathrm{r} / \mathrm{min}, 6 \mathrm{~h}\end{array}$ & 31.5 & $11.3\left(S_{\text {DHA }}\right)$ & [113] \\
\hline $\begin{array}{l}\mathrm{Pt} / \mathrm{NCNT}^{+} \\
\mathrm{Bi}\left(\mathrm{NO}_{3}\right)_{3} \cdot \mathrm{H}_{2} \mathrm{O}\end{array}$ & $\begin{array}{l}50 \mathrm{~g} \text { of } 10 \mathrm{wt} \% \mathrm{GLY} \text { aqueous solution, } 0.1 \mathrm{~g} \text { catalyst, } 333 \mathrm{~K}, \mathrm{O}_{2} 150 \mathrm{~mL} / \mathrm{min}, 600 \\
\mathrm{r} / \mathrm{min}, 6 \mathrm{~h}\end{array}$ & 29.3 & $64.4\left(S_{\mathrm{DHA}}\right)$ & [113] \\
\hline Pt-Bi/MWCNT & GLY solution $(0.1 \mathrm{~g} / \mathrm{mL}, 50 \mathrm{~mL}), 0.5 \mathrm{~g}$ catalyst, $333 \mathrm{~K}, \mathrm{O}_{2} 150 \mathrm{~mL} / \mathrm{min}$ & $500.8 \mathrm{~h}^{-1 \mathrm{~d}}$ & $\begin{array}{l}86.7\left(S_{\mathrm{DHA}}\right)^{\mathrm{e}} \\
9.7\left(S_{\mathrm{GLYA}}\right)^{\mathrm{e}}\end{array}$ & [107] \\
\hline PtSb/MWCNTs & GLY solution $(0.1 \mathrm{~g} / \mathrm{mL}, 50 \mathrm{~mL}), 0.5 \mathrm{~g}$ catalyst, $333 \mathrm{~K}, \mathrm{O}_{2} 150 \mathrm{~mL} / \mathrm{min}$ & $878.1 \mathrm{~h}^{-1 \mathrm{~d}}$ & $\begin{array}{l}80.8\left(S_{\text {DHA }}\right)^{\mathrm{e}} \\
15.0\left(S_{\mathrm{GLYA}}\right)^{\mathrm{e}}\end{array}$ & [107] \\
\hline $\mathrm{PtSb}_{1} / \mathrm{NCNT}$ & $\begin{array}{l}50 \mathrm{~g} \text { of } 10 \mathrm{wt} . \% \mathrm{GLY} \text { aqueous solution, } 0.1 \mathrm{~g} \text { catalyst, } 333 \mathrm{~K}, \mathrm{O}_{2} 150 \mathrm{~mL} / \mathrm{min}, 600 \\
\mathrm{r} / \mathrm{min}, 6 \mathrm{~h}\end{array}$ & 50.9 & $38.1\left(S_{\mathrm{DHA}}\right)$ & [113] \\
\hline
\end{tabular}


Table 1 (continued)

\begin{tabular}{|c|c|c|c|c|}
\hline Catalyst & Reaction conditions & $\begin{array}{l}\text { Conv. }{ }^{\mathrm{a}}(\%) \text { or } \\
\text { TOF }\left(\mathrm{h}^{-1}\right)\end{array}$ & $\begin{array}{c}\text { Selectivity and } \\
\text { yield }^{\mathrm{b}}(\%)\end{array}$ & Ref. \\
\hline $\mathrm{Au} / \mathrm{CuO}$ & $\begin{array}{l}\text { GLY solution }(0.1 \mathrm{~mol} / \mathrm{L}, 20 \mathrm{~mL}), \mathrm{GLY} / \mathrm{Au}=1000 \mathrm{~mol} / \mathrm{mol}, \mathrm{pH}=6.7,353 \mathrm{~K} \text {, } \\
\mathrm{O}_{2} 1 \mathrm{MPa} \text {, stirring speed }=900 \mathrm{rpm}, 2 \mathrm{~h}\end{array}$ & 19.4 & $83.3\left(S_{\mathrm{DHA}}\right)$ & [67] \\
\hline $\mathrm{Au} / \mathrm{Al}_{2} \mathrm{O}_{3}$ & $\begin{array}{c}\text { GLY solution (0.1 mol/L, } 20 \mathrm{~mL}), \mathrm{GLY} / \mathrm{Au}=315 \mathrm{~mol} / \mathrm{mol}, 353 \mathrm{~K}, 1 \mathrm{MPa} \text {, } \\
900 \mathrm{r} / \mathrm{min}, 3 \mathrm{~h}\end{array}$ & 11.9 & $\begin{array}{l}81.7\left(S_{\mathrm{DHA}}\right) \\
4.4\left(S_{\mathrm{GLYA}}\right)\end{array}$ & [68] \\
\hline $\mathrm{Au} / \mathrm{MgO}-\mathrm{Al}_{2} \mathrm{O}_{3}(4.8)$ & $\begin{array}{c}\text { GLY solution }(0.1 \mathrm{~mol} / \mathrm{L}, 20 \mathrm{~mL}), \mathrm{GLY} / \mathrm{Au}=315 \mathrm{~mol} / \mathrm{mol}, 353 \mathrm{~K}, 1 \mathrm{MPa} \text {, } \\
900 \mathrm{r} / \mathrm{min}, 12 \mathrm{~h}\end{array}$ & 13.9 & $\begin{array}{l}10.9\left(S_{\mathrm{DHA}}\right) \\
49.0\left(S_{\mathrm{GLYA}}\right)\end{array}$ & {$[68]$} \\
\hline $0.6 \% \mathrm{Bi} 3 \% \mathrm{Pt} / \mathrm{KL}$ & $50 \%$ aqueous solution of GLY, LHSV $0.06 \mathrm{~h}^{-1}$, oxygen/GLY mole ratio $=2,323 \mathrm{~K}$. & $40-50$ & $70-80\left(S_{\mathrm{DHA}}\right)$ & [102] \\
\hline $\mathrm{Au}: \mathrm{Pd}=50: 50$ & $\begin{array}{c}\text { Catalyst: } 5.0 \mathrm{~g}(8.3 \mathrm{~mL}), 333 \mathrm{~K} \text {, feed mixed solution liquid flow } \\
\text { (glycerol } 0.3 \mathrm{~mol} / \mathrm{L}+\mathrm{NaOH} 1.2 \mathrm{~mol} / \mathrm{L})\end{array}$ & 50 & $\begin{array}{l}60\left(S_{\mathrm{GLYA}}\right) \\
30\left(S_{\mathrm{TARAC}}\right)\end{array}$ & [118] \\
\hline $\mathrm{Au} / \mathrm{Al}_{2} \mathrm{O}_{3}$ & GLY $0.6 \mathrm{~mol} / \mathrm{L}, \mathrm{NaOH} 2.4 \mathrm{~mol} / \mathrm{L}, 0.25 \mathrm{~mL} / \mathrm{min}, \mathrm{O}_{2} 6.0 \mathrm{~mL} / \mathrm{min}$, catalyst $0.5 \mathrm{~g}, 3 \mathrm{~h}$ & 26.3 & $\begin{array}{c}37.7\left(S_{\text {GLYA }}\right) \\
42.7\left(S_{\text {TARAC }}\right)\end{array}$ & [119] \\
\hline $\mathrm{AuPt} / \mathrm{AC}$ & GLY $5 \mathrm{wt} \%, \mathrm{O}_{2} 15 \mathrm{~mL} / \mathrm{min}, \mathrm{LHSV}=0.046 \mathrm{~h}^{-1}, 333 \mathrm{~K}$ & 29.2 & $68.3\left(S_{\mathrm{GLYA}}\right)$ & [120] \\
\hline $\mathrm{Bi}-\mathrm{AuPt} / \mathrm{AC}$ & GLY 5 wt\%, $\mathrm{O}_{2} 5 \mathrm{~mL} / \mathrm{min}, \mathrm{LHSV}=0.092 \mathrm{~h}^{-1}, 333 \mathrm{~K}$ & 28.5 & $47.8\left(S_{\mathrm{DHA}}\right)$ & [120] \\
\hline FeS-s873 & GLY $0.012 \mathrm{~mL} / \mathrm{min}, \mathrm{O}_{2} / \mathrm{GLY}=3.5, \mathrm{GHSV}=52900 \mathrm{~h}^{-1}, 623 \mathrm{~K}$ & 100 & $88\left(S_{\text {DHA }}\right)$ & [121] \\
\hline
\end{tabular}

a Conversion of glycerol.

b Selectivity and yield of GLYA and/or DHA.

c Moles of glycerol converted per hour per mole of the metal calculated after 15 min of reaction.

d TOF was calculated at $10 \%$ glycerol conversion.

e Selectivity was calculated at $10 \%$ glycerol conversion.

\section{Selective oxidation of glycerol in a base-free aqueous solution}

\subsection{Selective oxidation of the terminal hydroxyl in glycerol}

One drawback of using base additives is that organic salts are mainly formed during the reaction, and further separation and processing (neutralization and acidification) is required for obtaining the free acids. These procedures are environmentally unfriendly and strong adsorption of intermediates on the catalyst would mask their real activity and product distribution. From the viewpoint of industrial application, it is desirable to directly obtain free products under acidic reaction conditions.

Considering the structure of glycerol, products such as GLYHD and GLYA can be obtained directly when the terminal hydroxyl of glycerol is oxidized under base-free conditions. GLYA and its derivatives have many biological functions, for example, D-glycerate can promote ethanol catabolism in a human body and oligomers of the GLYA-derived ester have antitrypsin activity. At the same time, GLYA can be used as a food additive. Currently, these products are produced in a time-consuming fermentation process. In this case, selective oxidation of the terminal hydroxyl of glycerol to GLYA and GLYHD is of great importance for both academic research and industrial application.

\subsubsection{Monometallic Pt catalysts}

In 2009, for the first time, we prepared a MWCNT-supported Pt catalyst and used it in the selective oxidation of glycerol under base-free conditions [69]. We found that the Pt/MWCNT catalyst is efficient for the oxidation of glycerol without any added base, and the conversion of glycerol reached $70.1 \%$ with $69.8 \%$ selectivity for free GLYA at $333 \mathrm{~K}$, with the (mole of glycerol) $/ \mathrm{Pt}=500$ in the feed. At the same time, we found that Pt/MWCNTs performed better than the traditional active carbon (AC)-supported Pt catalyst (Pt/AC), which we attributed to the easier accessibility of glycerol to $\mathrm{Pt}$ particles, because Pt particles tend to deposit on the external walls of MWCNTs. However, Pt particles were dispersed unevenly on the surface of pristine MWCNTs.

After that, a series of Pt NPs with different particle sizes (from 1.2 to $26.5 \mathrm{~nm}$ ) were fabricated on the surface of traditional active carbon and tested in the selective oxidation of glycerol in a base-free solution. In these reactions, larger Pt particles $(>10 \mathrm{~nm})$ were less active, and mainly intermediate products (aldehyde) were found to be formed instead of GLYA [70]. These results were similar with those published data and widely accepted reaction mechanism (that is, without the help of base, Pt is inactive for the formation of GLYA) [5,53,71]. However, interestingly, the conversion of glycerol increased with the decrease in particle size of Pt (for particle size smaller than $6 \mathrm{~nm}$ ), and the best yield of free GLYA over 3.3-nm Pt particles of $47.4 \%$ was achieved [70]. Unfortunately, decreasing the particle size of Pt from $3.3 \mathrm{~nm}$ to $1.2 \mathrm{~nm}$ (on the surface of active carbon) could not lead to further improvement in the conversion of glycerol, because the diffusion of glycerol, which is very viscous, into the micropores of active carbon is difficult.

In order to disclose the actual relationship between the particle size of $\mathrm{Pt}$ and its performance in the selective oxidation of glycerol in a base-free solution (by overcoming the possible negative effects of glycerol diffusion into the micropore of active carbon), highly dispersed and unique sized Pt NPs (2.0 nm) were fabricated on the surface of MWCNTs in our laboratory [72]. This catalyst was found to be extremely active and selective oxidation of glycerol without the addition of any base was achieved, with the selectivity of isolated GLYA reaching 68.3\% at $90.4 \%$ conversion of glycerol and the calculated turnover frequency (TOF) of all $\mathrm{Pt}$ atoms reaching $336.6 \mathrm{~h}^{-1}$ (at $10 \%$ conversion of glycerol) at $333 \mathrm{~K}$. At the same time, it was also found that the base additive $(\mathrm{NaOH})$ could accelerate the conversion of glycerol over Pt/S-MWCNTs; however, the use of $\mathrm{NaOH}$ led to severe $\mathrm{C}-\mathrm{C}$ bond cleavage because $\mathrm{H}_{2} \mathrm{O}_{2}$ formed 


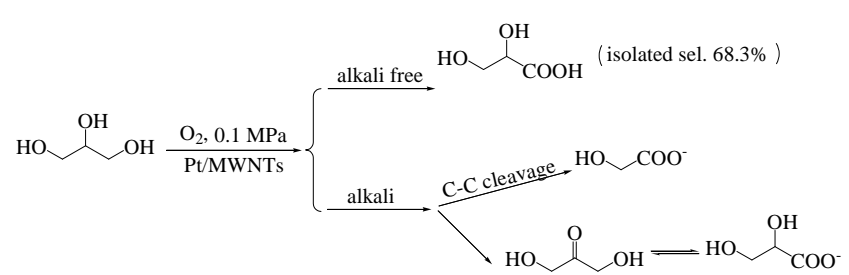

Fig. 4. Oxidation of glycerol over Pt/MWCNTs in the presence and absence of an alkali Reprinted with permission from [72], Copyright (2011) Elsevier.

easily in the basic solution [71,72], and the formed $\mathrm{H}_{2} \mathrm{O}_{2}$ catalyzed the $\mathrm{C}-\mathrm{C}$ bond cleavage (Fig. 4).

More recently, the selectivity of GLYA could be increased further to $83.2 \%$ (with $89.9 \%$ conversion of glycerol) over micropore-free carbon nanofiber-supported Pt NPs $(1.5 \mathrm{~nm})$ prepared in a similar fashion as the aforementioned Pt/S-MWCNTs [73]. These results confirmed that these catalysts with smaller metal particles (higher metal dispersion) exhibited better performance in the oxidation of glycerol and the selectivity of GLYA also increased with a decrease in particle size of Pt.

Similar works from other research groups also confirmed that MWCNT is a favorable support for Pt NPs in the selective oxidation of glycerol [74]. The conversion of glycerol reached 63.0\% with $37.6 \%$ selectivity for GLYA over $5.0 \mathrm{wt} \% \mathrm{Pt} / \mathrm{CNTs}$ (2.5-nm Pt NPs) catalyst under the base-free condition; however, strong adsorption of intermediates on the Pt NPs would mask their real activity (when the size of Pt NPs is less than 2.5 $\mathrm{nm}$ ), which is the main reason for the decreased activity. Li et al. [75] found that higher Pt loadings on the surface of $\mathrm{SiO}_{2}$ led to larger Pt NPs, resulting in a higher intrinsic activity that promoted the oxidation of the terminal alcohol groups of glycerol. Further, cuboctahedral Pt NPs exhibited higher turnover frequencies than tetrahedral Pt NPs but did not significantly influence the GLYA selectivity. Moreover, Tan et al. [76] suggested that basic sites on the surface of mesoporous carbon-supported Pt catalysts can promote the rate-determining step, the abstraction of hydrogen from the alcohol group, and thus improve the conversion of glycerol, while the surface oxygen groups can also increase the GLYA selectivity.

However, Pt-based catalysts are easily deactivated during the oxidation of glycerol with molecular oxygen because of the weak interaction between the carbon support and Pt, and leaching, agglomeration, and over-oxidation of the metal NPs, and/or strong adsorption of acids or ketone [77,78]. Many endeavors to overcome this drawback have been reported in recent years. Among these works, it was widely accepted that $\mathrm{N}$ atoms in the framework of the carbon support can donate electrons to $\mathrm{Pt}$, thereby enhancing the interaction between the support (MWCNTs [79-81], carbon fibers [73], mesoporous carbon nitride [82], etc.) and the metal, thus improving the dispersion, activity, and stability of Pt [81], and/or generating new active centers [83].

Chen et al. [79] found that incorporating $\mathrm{N}$ atoms in CNTs would increase the surface basicity, which accelerates the activation of $-\mathrm{OH}$ groups in glycerol, resulting in higher conversion and selectivity over Pt/N-CNTs than those over Pt/CNTs. The detected conversion of glycerol increased obviously from $51.5 \%$ (over $1 \%$ Pt/CNTs-353) to $76.1 \%$ (over 1\% Pt/N-CNTs), and the corresponding GLYA selectivity also increased from $43.2 \%$ to $55.6 \%$ at $333 \mathrm{~K}$. On the surface of ordered mesoporous carbon nitride (MCN)-supported Pt catalysts, the particle size of Pt was found to decrease from 3.4 to $2.3 \mathrm{~nm}$ with an increase in the $\mathrm{N}$ content from $2.6 \%$ to $9.4 \%$, and thus, the conversion of glycerol and the selectivity of GLYA also increased from $37.7 \%$ and $35.8 \%$ to $63.1 \%$ and $58.5 \%$, respectively [82]. Recent works of Ning et al. $[80,81]$ further disclosed that the graphitic nitrogen in the framework of a carbon support played an important role in determining the electronic properties of Pt NPs; it preferentially interacted with Pt NPs, donated electrons to metallic Pt NPs, and the electron-enriched Pt NPs tended to have a smaller particle size and possess enhanced activity.

Based on these achievements, Pt NPs supported on N-doped MWCNTs [84] and commercial XC-72 [85] were prepared and tested in the selective oxidation of glycerol in our laboratory. $\mathrm{Pt}$ NPs supported on both N-MWCNT and $\mathrm{N}_{5.2} \mathrm{C}-\mathrm{XC}-72$ showed significantly enhanced activity and stability in this reaction compared to the Pt NPs on unmodified supports. Further, Pt NPs (1.2 nm) supported on hybrid MWCNT-pillared nitrogen-doped graphene (NG) (Fig. 5) showed further increased activity, selectivity, and stability than the separated $\mathrm{Pt} / \mathrm{N}-\mathrm{MWCNTs}$ and Pt/CN $\mathrm{C}_{\mathrm{x}} \mathrm{NG}$; the specific activity of each surface Pt atom on the hybrid NG-MWCNTs support (267.2 $\mathrm{h}^{-1}$, average value in $3 \mathrm{~h}$ ) was found to be $20 \%$ higher than that on N-MWCNTs and $\mathrm{CN}_{\mathrm{X}}-\mathrm{NG}$ [86].

More recently, carbon film-encapsulated Pt NPs supported on MWCNTs (Pt@C-MWCNTs) were synthesized and used in the selective oxidation of glycerol in an acidic aqueous solution [78]. The Pt@C-MWCNTs exhibited both higher activity and extremely high stability than the bare Pt NPs. Characterization indicated that the carbon film encapsulation can retard the sintering of Pt NPs and prevent it from leaching. More interestingly, carbon film can suppress the over-oxidation of Pt NPs when it is exposed to $\mathrm{O}_{2}$ atmosphere and prevent the strong adsorption of organic carboxylic acids on Pt (Fig. 6).

\subsubsection{Bimetallic Pt-M based catalysts}

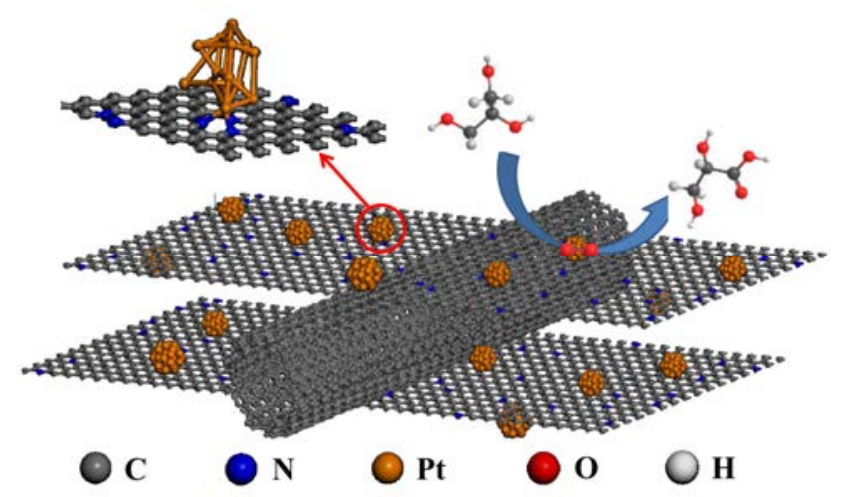

Fig. 5. Oxidation of glycerol over hybrid Pt NPs supported on NG-MWCNTs. Reprinted with permission from [86], Copyright (2017) Elsevier. 

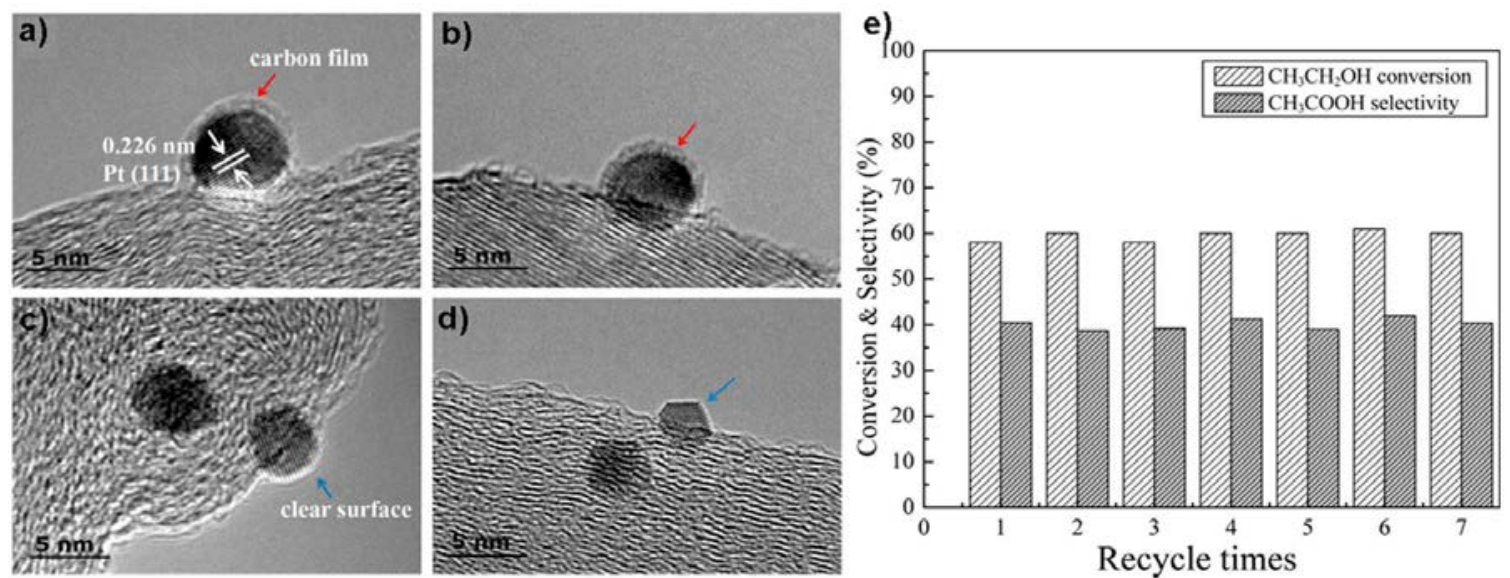

Fig. 6. High-resolution transmission electron micrographs of Pt@C-MWCNTs (a and b) and naked Pt/MWCNTs (c and d); (e) Recycling of Pt@C-MWCNTs for oxidation. Reprinted with permission from [78], Copyright (2017) Elsevier.

Apart from the doping of $\mathrm{N}$ into the carbon support, addition and/or alloying Pt with another metal is also an effective approach to overcome the deactivation of Pt NPs catalysts. Because bimetallic systems can modify the chemical properties of the separate partners, particle sintering during thermal treatments is inhibited and the effect of active site blockage is weakened, and these catalysts have the advantages of greater activity, higher selectivity, and harder deactivation compared to a single-metal catalyst $[39,87,88]$. It has been widely reported that single-metal gold catalyst is inactive in the oxidation of glycerol without the help of a base [89], while bimetallic Au-Pt catalyst is active in the oxidation of glycerol under base-free conditions [90-93]. In 2010, Villa et al. [89] reported that AuPt NPs on H-mordenite can selectively oxidize glycerol to GLYA under base-free conditions. AuPt/H-mordenite exhibited a significantly enhanced activity and increased selectivity to GLYA compared to $1 \%$ Au/H-mordenite and $1 \%$ $\mathrm{Pt} / \mathrm{H}-\mathrm{mordenite}$ under the same reaction conditions, and the conversion of glycerol over 1\% AuPt(6:4)/H-mordenite reached $70 \%$ with $83 \%$ GLYA selectivity. Alloying Au with Pt also prevented the leaching of the metals, thus improving the catalyst life. However, the reaction over AuPt/H-mordenite requires a high temperature $(373 \mathrm{~K})$. Oxidation of glycerol using $\mathrm{Mg}(\mathrm{OH})_{2}$-supported AuPt catalyst with a high conversion and selectivity to $\mathrm{C}_{3}$ products (GLYA and TARAC) at ambient temperatures under base-free conditions was reported by Brett et al. [92]. Among the tested catalysts, AuPt $(1: 3) / \mathrm{Mg}(\mathrm{OH})_{2}$ showed a significantly enhanced activity with $42.5 \%$ conversion of glycerol and $85.1 \%$ GLYA selectivity at $296 \mathrm{~K}, 300 \mathrm{kPa}$ $\mathrm{O}_{2}$, and glycerol to metal ratio of 500 .

Considering the low abundance and price of noble metals, addition of other base metals was also explored by several research groups, among which, copper has attracted much attention in the selective oxidation of glycerol owing to its advantages in the dehydrogenation of glycerol and lower activity for C-C bond cleavage [67,94]. In 2011, a series of carbon-supported bimetallic Pt-Cu catalysts were prepared in our laboratory and applied in the selective oxidation of glycerol with molecular oxygen under base-free conditions. The newly formed $\mathrm{PtCu}_{3}$ alloy had significantly improved activity and reduced the $\mathrm{C}-\mathrm{C}$ bond cleavage. The highest specific activity of all added $\mathrm{Pt}$ atoms reached $169 \mathrm{~h}^{-1}$ (average value in $6 \mathrm{~h}$ ), and the best yield of GLYA reached $61 \%$ with $86.2 \%$ conversion of glycerol at $333 \mathrm{~K}(6 \mathrm{~h})$. Even a $3 \mathrm{wt} \% \mathrm{Pt}-\mathrm{Cu} / \mathrm{C}$ catalyst (with lower loading of $\mathrm{Pt}$ ) showed a better activity than monometallic $5 \mathrm{wt} \% \mathrm{Pt} / \mathrm{C}$ [95]. And more recently, highly dispersed PtCo bimetallic NPs were fabricated on reduced graphene oxide (RGO) and used in the selective oxidation of glycerol. Co-modified Pt catalyst was found to be highly selective for the formation of GLYA (the selectivity of GLYA reached 85.9\% at $70.2 \%$ conversion of glycerol), and no obvious deactivation was observed after five times of reusing the catalyst [96]. Dou et al. [97] also reported a series of Sn-incorporated Pt/C catalysts with different $\mathrm{Pt} / \mathrm{Sn}$ ratios in the selective oxidation of glycerol. They found that the specific activity (TOF) of surface Pt atoms in $2.0 \% \mathrm{Pt}_{9} \mathrm{Sn}_{1} / \mathrm{C}-\mathrm{R}$ reached $938 \mathrm{~h}^{-1}(333 \mathrm{~K}, 2 \mathrm{~h})$, which is three times as high as that of $2.0 \% \mathrm{Pt} / \mathrm{C}-\mathrm{R}$ catalyst $\left(281 \mathrm{~h}^{-1}\right)$. These improvements were attributed to the activation of oxygen molecules and/or deprotonation of hydroxyl groups by the surface stannous oxide (SnO) species [97]. In addition, modifying Pt NPs with Sn can also enhance the stability of $\mathrm{Pt}_{9} \mathrm{Sn}_{1} / \mathrm{C}-\mathrm{R}$ and no substantial loss of activity was detected after four recycles.

Multi-metal catalysts such as supported Au-Pd-Pt catalysts have also been reported for the oxidation of glycerol in a base-free solution by Kondrat et al. [98]. They found that the specific activity of trimetallic $\mathrm{Au}-\mathrm{Pd}-\mathrm{Pt} / \mathrm{TiO}_{2}$ catalyst reached $378 \mathrm{~h}^{-1}$, which is higher than those of $\mathrm{Pd}-\mathrm{Pt} / \mathrm{TiO}_{2}\left(210 \mathrm{~h}^{-1}\right)$, $\mathrm{Au}-\mathrm{Pd} / \mathrm{TiO}_{2}\left(38 \mathrm{~h}^{-1}\right)$, and $\mathrm{Au}-\mathrm{Pt} / \mathrm{TiO}_{2}$. Further, the selectivity of the reaction catalyzed by the trimetallic $\mathrm{Au}-\mathrm{Pd}-\mathrm{Pt} / \mathrm{TiO}_{2}$ catalyst towards $\mathrm{C}_{3}$ products remained same as that of $\mathrm{Pd}-\mathrm{Pt} / \mathrm{TiO}_{2}$.

\subsubsection{Acid-base properties of the support}

Recently, several groups also disclosed that the acid-base properties of support have a significant influence on the performance of catalysts in terms of their activity and selectivity $[99,100]$. Basic supports such as $\mathrm{MgO}$ and $\mathrm{NiO}$ can promote the activity of supported AuPt NPs in the oxidation of glycerol in a 


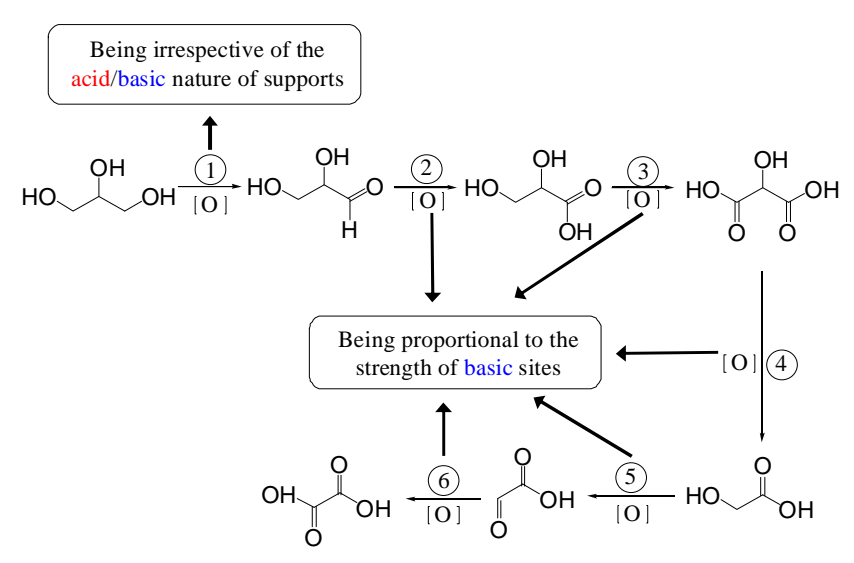

Fig. 7. Relationship between acid/basic nature of supports and reaction rates. Reprinted with permission from [100], Copyright (2015) Elsevier.

base-free solution, but decrease the selectivity to $C_{3}$ products because of the increased $\mathrm{C}-\mathrm{C}$ bond cleavage reactions. In contrast, AuPt catalysts supported on acidic supports such as $\mathrm{H}$-mordenite, $\mathrm{SiO}_{2}, \mathrm{MCM}-41$, and sulfated $\mathrm{ZrO}_{2}$ showed enhanced selectivity to $\mathrm{C}_{3}$ products, and the increased number of acid sites (Brønsted sites and/or silanols) can promote the successive transformation of GLYHD to GLYA via an acid-catalyzed geminal diol formation and its dehydrogenation to a carboxylic acid [99]. Xu et al. [100] found that the selectivity of GLYHD decreased with the strength of the basic sites on the surface of supported AuPt NPs, and the selectivity of TARAC (or glycolic acid or glyoxalic acid) increased with the strength of the basic sites. The product distributions could be adjusted by tuning the strength of the basic sites. Figure 7 shows the relationship between the acid/basic properties of the supports and reaction rates. The amount of formed GLYA depended on the relative reaction rate of reactions (2) and (3), with increasing reaction (2) and decreasing reaction (3) contributing to the formation of GLYA. Among these steps, the rates of reactions (2)-(6) depended on the acid/basic properties of the catalyst supports. On the surface of AuPt/MgO catalyst that has strong basic sites $\left(\mathrm{Mg}-\mathrm{OH}^{-}\right)$, the selectivity to GLYA was relatively low. Replacing the strong basic sites with other weak basic sites

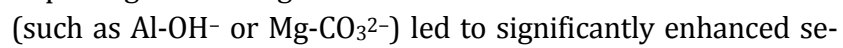
lectivity to GLYA. These results indicated that the replacement of weaker basic sites can decrease the density of $\mathrm{Mg}-\mathrm{OH}^{-}$base sites and retard the rate of the deep oxidation of GLYA (reactions (3)-(6)).

Tongsakul et al. [93] found that Pt/Au alloy NPs supported on hydrotalcites $\left(\mathrm{Pt}_{x} \mathrm{Au}_{y}\right.$-starch/HTs) can catalyze the oxidation of glycerol to GLYA at room temperature under base-free conditions. The selectivity of GLYA was $57 \%$ at $73 \%$ conversion of glycerol over $\mathrm{Pt}_{60} \mathrm{Au}_{40}$-starch/HTs. Figure 8 shows the reaction mechanism of glycerol oxidation over PtAu-starch/HT. Electrons could transfer from starch ligand to both $\mathrm{Au}$ and Pt atoms, and the excess electrons on the Au atoms could further transfer to Pt atoms. The electron-enriched Pt atoms can enhance the absorption of oxygen and generate anionic oxygen, such as superoxo or peroxo species (1). The abstraction of proton from glycerol on the basic support results in the formation of the corresponding alkoxide (2). Aldehyde and $\mathrm{H}_{2} \mathrm{O}$ are released to generate the peroxo species after the transfer of the proton from the adsorbed alkoxide carbon to the adsorbed oxygen $(3,4)$. Aldehyde is attracted by the adjacent metal atom with adsorbed oxygen ( $\mathrm{Au}$ atoms) (5), and then, the nucleophilic oxygen atom of water attacks the electron-deficient carbonyl carbon (6). Further, the adsorbed oxygen can abstract the proton to yield the carboxylic acid (7) and change to the peroxo species (8) to complete the catalytic cycle.

\subsection{Selective oxidation of the secondary hydroxyl in glycerol}

DHA, the product of oxidation of the secondary OH of glycerol, is an important intermediate in cosmetics and organic synthesis [12]. Currently, DHA is produced via the microbial fermentation of glycerol by gluconobacter oxydans, which has low productivity because of the low substrate concentration and the long fermentation time [101]. Selective oxidation of glycerol to DHA in a heterogeneous process using a solid catalyst is highly attractive both for academic research and industrial application.

\subsubsection{Pt-Bi catalysts}

In 1993, Kimura et al. [53,102] found that an active carbon-supported $1 \% \mathrm{Bi}-5 \% \mathrm{Pt} / \mathrm{C}$ catalyst can promote the formation of DHA directly from the heterogeneous oxidation of glycerol with molecular oxygen. The best yield of DHA reached $20 \%$ at $30 \%$ conversion of glycerol in a batch reactor under $\mathrm{pH}$ 2-4 and 0.1 MPa air atmosphere at $323 \mathrm{~K}$. In a continuous liq-

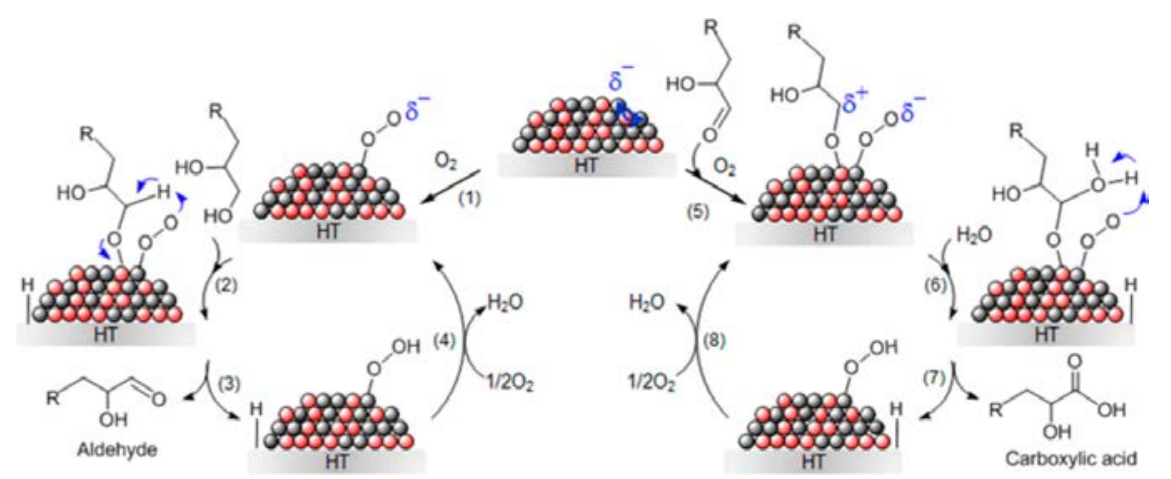

Fig. 8. Reaction mechanism for the polyol oxidation catalyzed by PtAu-starch/HT. Reprinted with permission from [93], Copyright (2003) American Chemical Society. 


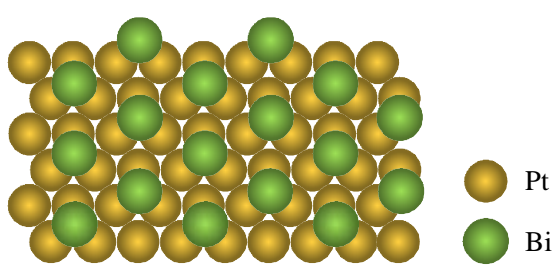

Fig. 9. The site-block effect of Bi on a Pt catalyst. Reprinted with permission from [102], Copyright (1993) Elsevier.

uid-solid fixed-bed reactor, the best yield of DHA can be increased to $30 \%$ (at $40 \%$ conversion of glycerol) over a granular charcoal-supported $0.6 \% \mathrm{Bi}-3 \% \mathrm{Pt}$ catalyst $[53,102]$. These results suggest that adding bismuth to supported Pt catalysts leads to improved catalytic activity and enhanced selectivity of the oxidation of secondary hydroxyl group of glycerol. Based on the performance of monometallic Pt and Bi-promoted Pt, Kimura et al. suggested that bismuth adatoms would serve as site blockers on $\operatorname{Pt}(111)$, thus preventing the catalyst poisoning caused by the irreversible adsorption of by-products, and they control the orientation of adsorbed glycerol towards formation of DHA (Fig. 9). Under optimized reaction conditions (with Pt-Bi/C catalyst), Garcia et al. [54] found that the yield of DHA could be increased to $37 \%$ (at $75 \%$ conversion of glycerol) in batch reactors.

After that, the structure of Bi-promoted Pt catalyst and the role of Bi additive were investigated intensively by several groups [53,54,102-111]. The suggested functions of Bi could be classified as follows: (a) the site-block effect of Bi adatoms $[102,103]$; (b) the formation of a complex among the noble metal, promoter, and reactant [104-106]; (c) prevention of the noble metal from over-oxidation [104]; (d) the formation of an alloy [107-109]; (e) prevention of the corrosion of metal catalysts [108]; and (f) formation of new active centers such as Bi-OHads [110,111].

A series of active carbon-supported bimetallic Pt-Bi catalysts with different $\mathrm{Bi}$ contents ranging from $3.0 \mathrm{wt} \%$ to 7.0 wt $\%$ were synthesized in our laboratory and used in the selective oxidation of glycerol to DHA in a liquid phase [112]. The addition of $\mathrm{Bi}$ increased the dispersion of Pt and accelerated the conversion of glycerol. The conversion of glycerol and the selectivity of DHA increased from $70.3 \%$ and $9.2 \%$ (over monometallic 5\% Pt/C) to $91.5 \%$ and $49.0 \%$ (over 5\% Pt-5\% Bi/C), respectively. Structural characterizations indicated that mainly $\mathrm{Bi}_{2} \mathrm{O}_{2} \mathrm{CO}_{3}$ formed with an increase in amount of $\mathrm{Bi}$, and no evidence was found to support the formation of the Bi-Pt alloy [112].

Recently, a series of controlled experiments were performed by Ning et al. [113], wherein, $\mathrm{Bi}\left(\mathrm{NO}_{3}\right)_{3} \cdot 5 \mathrm{H}_{2} \mathrm{O}$ was added separately to a reaction mixture containing glycerol, water, and Pt/NCNT catalyst. They found that mainly GLYHD formed over single Pt/NCNT catalyst, while DHA was the dominant product when $\mathrm{Bi}\left(\mathrm{NO}_{3}\right)_{3} \cdot 5 \mathrm{H}_{2} \mathrm{O}$ was added to the reaction mixture. The selectivity of DHA obviously increased from 11.3\% (over $\mathrm{Pt} / \mathrm{NCNT}$ ) to $64.4 \%$ (over Pt/NCNT $+\mathrm{Bi}\left(\mathrm{NO}_{3}\right)_{3} \cdot 5 \mathrm{H}_{2} \mathrm{O}$ ), while the corresponding conversion of glycerol remained almost the same. Based on these results, it was concluded that (1) the (a)<smiles>OCC(O)CO</smiles><smiles>O=CC(O)CO</smiles>
Glycerol GL YHD $-5$

(b)

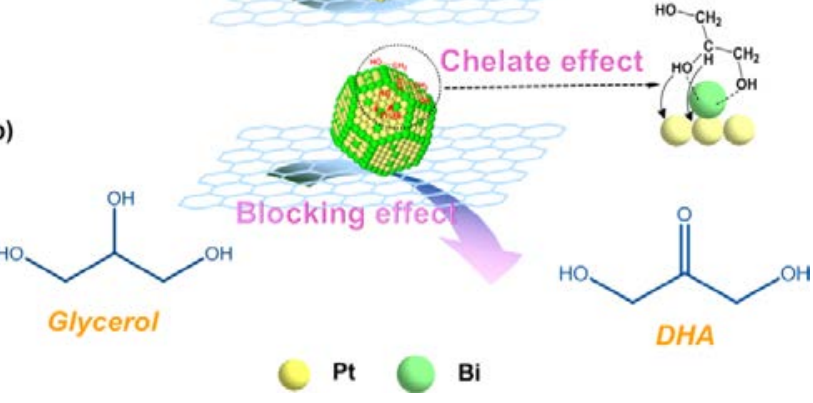

Fig. 10. Selective oxidation of glycerol (a) to GLYHD using Pt/NCNT and (b) to DHA using the Bix-Pt/NCNT (in situ) system. Reprinted with permission from [113], Copyright (2016) Elsevier.

high-energy Pt sites favored the adsorption and activation of primary hydroxyl groups or over-oxidation and transformation of DHA, (2) soluble $\mathrm{Bi}^{3+}$ occupied the high-energy step sites and then the terrace sites of Pt NPs, and (3) the formed Bi-Pt sites on the terrace surfaces of Pt NPs enhanced the selective oxidation of glycerol to DHA through the geometric blocking effect, as illustrated in Fig. 10.

Theoretical calculations by Xiao et al. [114] indicated that Bi atoms covering the surface of $\mathrm{Pt}(111)$ rather than those incorporated inside Pt are necessary for the selective formation of DHA from glycerol. They proposed a catalytic cycle over Pt-Bi for the formation of DHA from glycerol, as shown in Fig. 11. On the surface of $\mathrm{Bi}_{2}-\mathrm{Pt}(111)$, oxygen is first dissociatively adsorbed on a bismuth site to yield $\mathrm{Bi}_{2} \mathrm{O}-\mathrm{Pt}(111)$. After this, glycerol is adsorbed at the interface of $\mathrm{Bi}_{2} \mathrm{O}$ and $\mathrm{Pt}(111)$ to form a $\mathrm{Bi}_{2} \mathrm{O}-\mathrm{Pt}+\mathrm{GLY}^{*}$ complex. Then, simultaneous dehydrogenation of glycerol to $\mathrm{DHA}\left(\mathrm{Bi}_{2} \mathrm{OH}+\mathrm{PtH}+\mathrm{DHA}^{*}\right)$ and desorption of DHA $\left(\mathrm{Bi}_{2} \mathrm{OH}+\mathrm{PtH}\right)$ take place, and the cycle ends with the formation and desorption of $\mathrm{H}_{2} \mathrm{O}\left(\mathrm{Bi}_{2}-\mathrm{Pt}\right)$.

Several possible influencing factors such as the metal load-

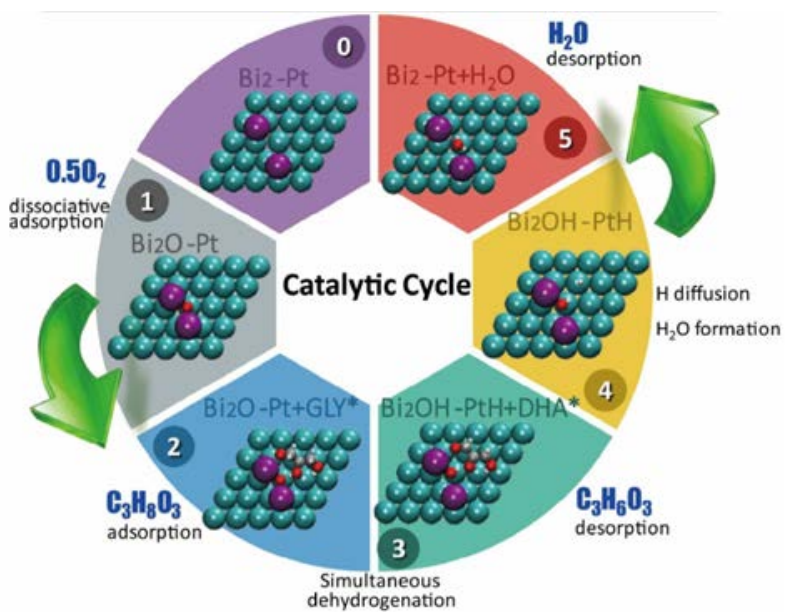

Fig. 11. Catalytic cycle of Pt-Bi for the formation of DHA from glycerol. Reprinted with permission from [114], Copyright (2016) John Wiley and Sons. 
ing, support, preparation method of $\mathrm{Pt}-\mathrm{Bi} / \mathrm{C}$, and reaction conditions were optimized by Hu et al. [115]. They concluded that an active carbon-supported catalyst with $3 \mathrm{wt} \% \mathrm{Pt}$ and $0.6 \mathrm{wt} \%$ Bi prepared via sequential impregnation followed by $\mathrm{NaBH}_{4}$ reduction is the most active for the formation of DHA. Further, they reported that increasing the gas pressure could promote the dissolution of oxygen in water, thus enhancing the conversion of glycerol. In addition, they also suggested that an acidic solution can slow the rate of oxidation of GLYHD to hydroxypyruvic acid, but also reduce the conversion of glycerol.

\subsubsection{Pt-Sb catalysts}

Bimetallic Pt-Bi catalysts are deactivated easily during the oxidation of glycerol with molecular oxygen, which is mainly caused by the strong adsorption of formed products (such as GLYA, GLYHD and/or hydroxypyruvic acid) on the catalyst $[78,116,117]$. GLYA tends to adsorb on the most active sites that are predominantly responsible for the formation of DHA; therefore, continuous removal of GLYA can result in complete conversion of glycerol and a tremendous increase in the selectivity of DHA [116].

In 2012, well-dispersed PtSb alloy NPs on the surface of MWCNTs, $\mathrm{Bi}_{2} \mathrm{O}_{3}$-half wrapped $\mathrm{Pt}(\mathrm{Bi}) \mathrm{NPs}$ supported on MWCNTs, and monometallic Pt NPs on MWCNTs were synthesized in our laboratory and used in the selective oxidation of glycerol in a base-free aqueous solution [107]. We found that $\mathrm{PtSb} / \mathrm{MWCNTs}$ is extremely active in the selective oxidation of glycerol to DHA, the TOF of the surface Pt atoms in $\mathrm{PtSb} / \mathrm{MWCNTs}$ increased from $341.5 \mathrm{~h}^{-1}$ (for Pt/MWCNTs) and $500.8 \mathrm{~h}^{-1}$ (for PtBi/MWCNTs) to $878.1 \mathrm{~h}^{-1}$ (PtSb/MWCNTs). At the same time, a series of controlled experiments disclosed DHA to be the primary product obtained from the oxidation of glycerol over both PtBi/MWCNTs and PtSb/MWCNTs, as the detected selectivity of DHA reached $86.7 \%$ and $80.8 \%$, respectively, at $10 \%$ oxidative conversion of glycerol. However, $\mathrm{PtBi} / \mathrm{MWCNTs}$ could also promote the consecutive oxidation of DHA to HPYA, with the selectivity of DHA decreasing quickly to $51.1 \%$ (at 50\% conversion of glycerol) and 35.6\% (at 90\% conversion of glycerol). In contrast, DHA was relatively "stable" on PtSb/MWCNTs under the same reaction condition. These results indicated that $\mathrm{PtSb}$ was less active in the further oxidation of DHA (Fig. 12). The recent work of Ning et al. [113] also confirmed that the addition of $\mathrm{Sb}$ can improve the formation of DHA. When the weight percentage of $\mathrm{Sb}$ was increased from 0 to $1 \%$, the selectivity of DHA increased from $11.1 \%$ (over $\mathrm{Pt} / \mathrm{NCNT}$ ) to $38.1 \%$ (over $\mathrm{PtSb}_{1} / \mathrm{NCNT}$ ), and the corresponding conversion of glycerol increased from $31.5 \%$ to $50.9 \%$.

\subsubsection{Au-based catalysts}

More recently, the synthesis of a highly active $\mathrm{Au} / \mathrm{CuO}$ catalyst and its performance in the oxidation of glycerol without any base was reported by Liu et al. [67]. $\mathrm{Au} / \mathrm{CuO}$ showed a remarkable catalytic performance and led to $19.4 \%$ glycerol conversion with high selectivity towards DHA, which reached up to $80 \%$. In contrast, $\mathrm{Au}$ supported on other supports (such as $\mathrm{Al}_{2} \mathrm{O}_{3}, \mathrm{TiO}_{2}, \mathrm{NiO}$, and $\mathrm{ZrO}_{2}$ ) exhibited a poor activity in the oxidation of glycerol without a base $(\mathrm{NaOH})$. Further studies on the reactions of 1,2-propanediol and 1,3-propanediol, and unlabeled and deuterium-labeled 2-propanol and 1-propanol also demonstrated that Au NPs have a high activity and specific selectivity toward the oxidation of secondary alcohols under base-free conditions. Subsequent works by the same group further demonstrated that the acid-base property of the support played a crucial role in the product distributions during the oxidation of glycerol [68]. The selectivity of DHA decreased from $81.7 \%$ (over $\mathrm{Au} / \mathrm{Al}_{2} \mathrm{O}_{3}$ ) to $10.9 \%$ (over $\mathrm{Au} / \mathrm{MgO}-\mathrm{Al}_{2} \mathrm{O}_{3}$ $(\mathrm{Mg} / \mathrm{Al}=4.8)$ ), while that of GLYA increased from $4.4 \%$ (over $\mathrm{Au} / \mathrm{Al}_{2} \mathrm{O}_{3}$ ) to $\sim 49.0 \%$ (over $\mathrm{Au} / \mathrm{MgO}-\mathrm{Al}_{2} \mathrm{O}_{3}(\mathrm{Mg} / \mathrm{Al}=4.8$ )). That is, the product distributions can be tuned by modifying the acid-base property of the support, and an acidic surface is more favorable for the formation of DHA.

\section{Oxidation of glycerol in a continuous reactor}

According to most of the published works, the selective oxidation of glycerol was carried out in batch reactors (with high pressure oxygen in an autoclave or bubbling of oxygen under atmospheric pressure). However, continuous oxidation of glycerol over a solid catalyst is more favorable for the quick removal of the reactive intermediates (from the surface of the catalyst), ease of separation, and industrial application.

In the case of a continuous fixed-bed reactor packed with a $\mathrm{Pt}$-Bi catalyst (weight ratio of $\mathrm{Bi}$ to $\mathrm{Pt}=0.2$ ), when aqueous solution of glycerol was fed into the reactor with gaseous oxygen, the selectivity of DHA reached 70\%-80\% with $40 \%-50 \%$ conversion of glycerol in most experiments (at $323 \mathrm{~K}$ ) [102]. However, it is quite interesting that the conversion of glycerol increased from $\sim 25 \%$ (after $1 \mathrm{~h}$ ) to $\sim 80 \%$ (after $9 \mathrm{~h}$ ) with an increase in time on stream. Based on a series of experiments under different conditions, such as varied liquid hourly space velocity (LHSV), mole ratio of oxygen to glycerol in the feed, the presence or absence of $\mathrm{NaOH}$, the most striking feature of the

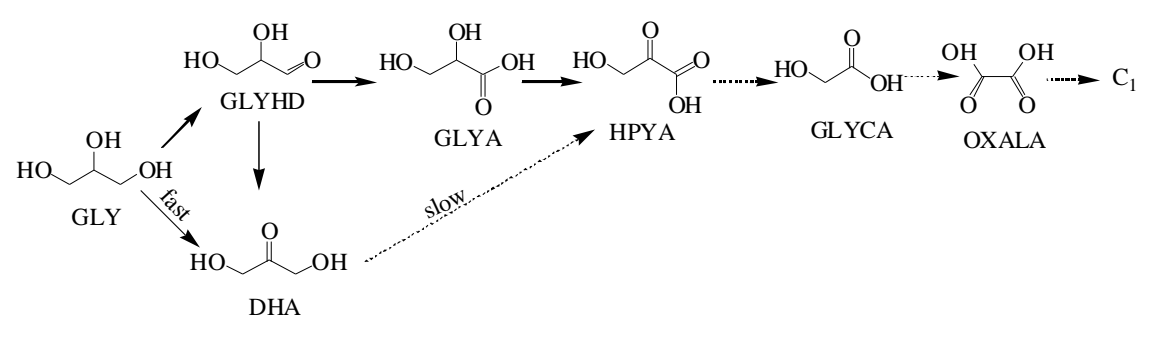

Fig. 12. Reaction sequences of selective oxidation of glycerol over PtSb/MWCNTs. Reprinted with permission from [107], Copyright (2012) Elsevier. 
continuous reaction was concluded to be the higher selectivity toward DHA (even at a higher conversion level). This could not be achieved in a batch reactor even when the catalyst amount was increased to more than $100 \%$ with respect to glycerol.

Recently, Mimura et al. [118] found that a commercial ion-exchange resin-supported Au-Pd NPs prepared by a two-step method (ion-exchange of a mixed solution of $\mathrm{Au}$ and Pd followed by reduction using $\mathrm{NaBH}_{4}$ ) showed better activity than that prepared by other methods (Au or Pd ion-exchange followed by reduction). Moreover, the ion-exchange resin-supported Au-Pd NPs were very stable with time on stream (> $4000 \mathrm{~min}$ ) in a fixed-bed flow-type reactor, and the conversion of glycerol reached $50 \%$ with $60 \%$ selectivity for GLYA at $333 \mathrm{~K}$ and $\mathrm{NaOH} /$ glycerol ratio of 4 . More recently, $\mathrm{Al}_{2} \mathrm{O}_{3}$-supported $\mathrm{Au}$ NPs were reported to be quite active in the continuous oxidation of glycerol to high-value carboxylic acids in a liquid-phase flow reactor [119]. The conversion of glycerol was disclosed to be higher than $70 \%$ with $80 \%$ selectivity for GLYA and TARAC at $343 \mathrm{~K}$ with $6.0 \mathrm{~mL} / \mathrm{min}_{2}, 0.25 \mathrm{~mL} / \mathrm{min}$ flow rate of mixed glycerol $(0.6 \mathrm{~mol} / \mathrm{L})$, and $\mathrm{NaOH}(2.4 \mathrm{~mol} / \mathrm{L})$.

The performances of AuPt/AC and Bi-modified AuPt/AC in the selective oxidation of glycerol in a continuous flow fixed-bed reactor under base-free conditions were compared by Motta et al. [120]. They observed that mainly GLYA formed (with $68.3 \%$ selectivity at $29.2 \%$ conversion of glycerol) over $\mathrm{AuPt} / \mathrm{AC}$ at $333 \mathrm{~K}$ with $5 \mathrm{~mL} / \mathrm{min}_{2}$ and $0.046 \mathrm{~h}^{-1} \mathrm{LHSV}$ of 5 $w t \%$ glycerol. However, the selectivity of DHA over Bi-AuPt/AC increased to $47.8 \%$ (with $28.5 \%$ conversion of glycerol) under $5 \mathrm{~mL} / \mathrm{min}_{2}$ and $0.092 \mathrm{~h}^{-1} \mathrm{LHSV}$ of $5 \mathrm{wt} \%$ glycerol. AuPt/AC was stable during $80 \mathrm{~h}$ of time on stream, whereas Bi-AuPt/AC showed significant structural modification because of the weaker metal-support interaction induced by the added Bi.

A novel chemocatalytic technology whereby glycerol can be continuously oxidized to DHA in the gas phase over iron-containing zeolite with molecular oxygen was reported by Lari et al. [121]. The performance of iron-containing materials was found to be significantly better than that of noble metal catalysts in the gas-phase oxidation of glycerol at $623 \mathrm{~K}$. Among iron-containing materials, iron-containing silicalite (FeS-s873) synthesized by a hydrothermal synthesis exhibited prominent activity and selectivity toward the formation of DHA. The best yield of DHA reached $88 \%$ with complete conversion of glycerol even when pure glycerol was used in the feed. The results of characterization indicated that optimal adjustment among the structure, acidity, and morphology of FeS-s873 would contribute to its excellent performance. That is, (1) the mild acidity of Fe-silicalite limited the formation of dehydration byproducts, and (2) highly dispersed iron species in the form of isolated cations or small $\mathrm{FeO}_{\mathrm{x}}$ clusters in extra framework positions finally led to a high selectivity of DHA. These results highlight the pathway to industrial applications.

\section{Summary and prospect}

Glycerol is a side-product formed during the production of biodiesel via transesterification, and the amount of glycerol has increased rapidly with the expansion of biodiesel production.
Since 2004, glycerol has been recommended as one of the most important chemicals in the bio-refinery process. According to the published works, several commodity chemicals (such as propanediols, acrolein, and ethanol/methanol), additives, and many fine chemicals could be prepared from glycerol.

In this review, we discussed the selective oxidation of glycerol with molecular oxygen over monometallic $\mathrm{Au}, \mathrm{Pt}$, and $\mathrm{Pd}$ NPs, and bimetallic Au-Pt, Au-Pd, Pt-Bi, Pt-Sb, Pt-Cu, and Pt-Co on different supports in detail. Early studies suggested the requirement of a base for the oxidation of glycerol, because the $\mathrm{OH}^{-}$in solution can abstract a proton from the primary hydroxyl groups of glycerol and initiate the oxidation process. However, the drawback of using base additives is that mainly organic salts are formed during the reaction, and further separation and processing (neutralization and acidification) are required to obtain the free acids.

Over the past decade, selective oxidation of glycerol under base-free conditions has been developed extensively. It was found that monometallic Pt clusters (sized in 1.0-3.0 nm) are capable of catalyzing the oxidation of glycerol to GLYA without a base, while large Pt NPs (>8.0 nm) are less active. However, Pt catalysts are easily deactivated during the oxidation of glycerol with molecular oxygen, because the interaction between the carbon support and metal particles is weaker, and particle agglomeration, metal leaching, over-oxidation of the surface metal NPs and/or strong adsorption of acids or ketones occur [78]. Metal leaching and sintering would cause the reconstruction of $\mathrm{Pt}$, leading to the irreversible deactivation of the Pt catalyst $[77,122,123]$. Over-oxidation of Pt NPs would result in an inactive oxide surface layer [124,125]. Moreover, strong adsorption of reactants, intermediates, products, or byproducts during catalytic reactions would block the active sites, resulting in the deactivation of the metal catalyst $[77,126,127]$. To overcome this, many efforts were made to improve the activity, selectivity, and stability of Pt-based catalysts. Among them, introducing heteroatoms (such as $\mathrm{N}$ ) into the carbon matrix support and alloying Pt with other metals (such as $\mathrm{Au}, \mathrm{Cu}, \mathrm{Bi}, \mathrm{Sb}$ and $\mathrm{Co}$ ) were proved to be valid. At the same time, it was confirmed that $\mathrm{Bi}$ and $\mathrm{Sb}$ can also function as site blockers on Pt NPs, and they can alter the orientation of adsorbed glycerol toward the formation of DHA and/or retard the deep oxidation of DHA (to GLYA, HPYA, TARAC, $\mathrm{HCOOH}$, and even $\mathrm{CO}_{\mathrm{x}}$ ).

According to the published works of Xu et al. $[67,68]$ on the glycerol oxidation over Au-based catalysts on supports with varied acidity/basicity, and our previous works on Pt[69,70,72,73,84-86], Pt-Cu [94], Pt-Co [95], Pt-Bi [102,107], and $\mathrm{Pt}-\mathrm{Sb}$ [107] catalysts in base-free aqueous solutions, we suggest that the scheme shown in Fig. 13 would be more reasonable for the oxidation of glycerol. That is, on the surface of basic oxides supported Au catalyst, and Pt-, Pt-Cu-, Pt-Co-based catalysts, oxidation of glycerol occurs mainly via the upper glycerol $\rightarrow$ GLYHD $\rightarrow$ GLYA sequence in a base-free solution, because GLYA is the dominant product. In contrast, DHA is the main intermediate as the oxidation of glycerol performed in the bottom sequence over acidic oxides supported $\mathrm{Au}$ catalyst, and Pt-Bi, Pt-Sb-based catalysts.

More recently, the selective oxidation of glycerol in a con- 


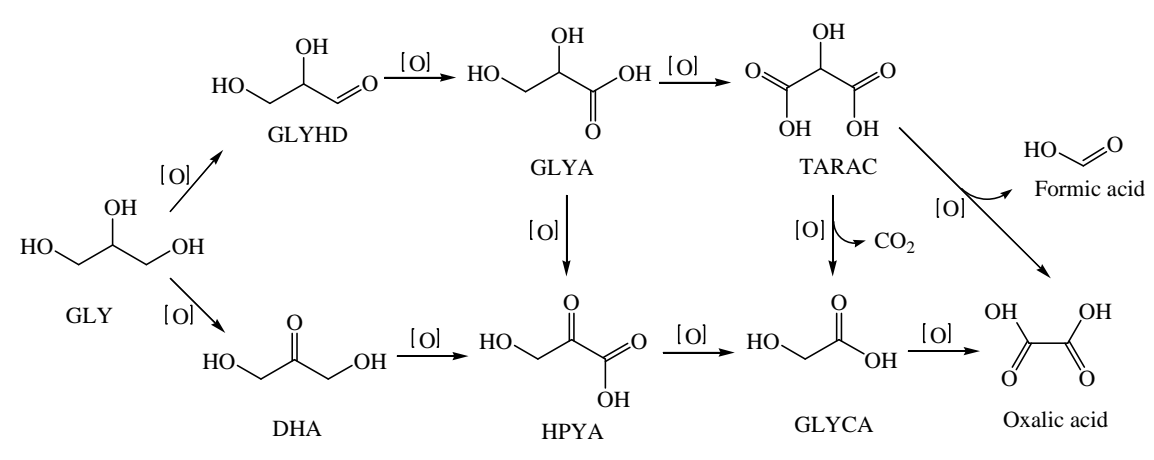

Fig. 13. The glycerol oxidation scheme.

tinuous liquid-phase fixed-bed reactor or gas-solid fixed-bed reactor has attracted the attention of several groups. Further, continuous oxidation of glycerol over solid catalysts was confirmed to be more favorable for the quick removal of formed DHA, ease of separation, and industrial application.

Finally, the selective oxidation of glycerol in a base-free condition is important for both academic research and industrial application, and obvious progresses were reported in the past years. However, subsequent works in the following areas are anticipated in the future: (1) an efficient method or technology for the mechanistic study on the complex gas (oxygen or air)-liquid (glycerol, products, and solvent)-solid (catalyst) mixture, (2) a stable catalyst that can overcome the deactivation caused by the over-oxidation and/or strong adsorption of acids or ketones on the surface of metal NPs, and (3) increasing the selectivity of DHA, because DHA has broad market demand and the separation of DHA from aqueous solution is a difficult task.

\section{References}

[1] C. H. Zhou, J. N. Beltramini, Y. X. Fan, G. Q. Lu, Chem. Soc. Rev., 2008, 37, 527-549.

[2] A. Talebian-Kiakalaieh, N. A. S. Amin, K. Rajaei, S. Tarighi, Appl. Energy, 2018, 230, 1347-1379.
[3] A. Almena, L. Bueno, M. Díez, M. Martín, Clean Technol. Environ. Policy, 2018, 20, 1639-1661.

[4] K. Kohse-Hoinghaus, P. Oßwald, T. A. Cool, T. Kasper, N. Hansen, F. Qi, C. K. Westbrook, P. R. Westmoreland, Angew. Chem. Int. Ed., 2010, 49, 3572-3597.

[5] R. Luque, L. Herrero-Davila, J. M. Campelo, J. H. Clark, J. M. Hidalgo, D. Luna, J. M. Marinas, A. A. Romero, Energy Environ. Sci., 2008, 1, 542-564.

[6] H. Zhang, H. Li, H. Pan, A. Wang, S. Souzanchi, C. B. Xu, S. Yang, Appl. Energy, 2018, 223, 416-429.

[7] H. Taher, S. Al-Zuhair, Biofuels Bioprod. Biorefining, 2017, 11, 168-194.

[8] F. Fantozzi, A. Frassoldati, P. Bartocci, G. Cinti, F. Quagliarini, G. Bidini, E. M. Ranzi, Appl. Energy, 2016, 184, 68-76.

[9] Y. X. Yi, Y. Shen, J. K. Sun, B. Wang, F. Xu, R. C. Sun, Chin. J. Catal,, 2014, 35, 757-762.

[10] J. Gaidukevic, J. Barkauskas, A. Malaika, P. Rechnia-Gorący, A. Mozdzynska, V. Jasulaitienèc, M. Kozłowski, Chin. J. Catal., 2018, 39, 1633-1645.

[11] J. J. Bozell, G. R. Petersen, Green Chem., 2010, 12, 539-554.

[12] B. Katryniok, H. Kimura, E. Skrzynska, J. Girardon, P. Fongarland, M. Capron, R. Ducoulombier, N. Mimura, S. Paul, F. Dumeignil, Green Chem., 2011, 13, 1960-1979.

[13] L. Z. Tao, S. H. Chai, Y. Zuo, W. T. Zheng, Y. Liang, B. Q. Xu, Catal. Today, 2010, 158, 310-316.

[14] F. Zhang, Y. Zhang, C. Chen, K. Dai, M. C. M. van Loosdrecht, R. J. Zeng, Appl. Energy, 2015, 148, 326-333.

\section{Graphical Abstract}

Chin. J. Catal., 2019, 40: 1020-1034 doi: S1872-2067(19)63301-2

\section{Selective oxidation of glycerol in a base-free aqueous solution:} A short review

Lihua Yang, Xuewen Li, Ping Chen, Zhaoyin Hou *

Zhejiang University, China

Recent progresses in the selective oxidation of glycerol with molecular oxygen were reviewed, and the performance of monometallic $\mathrm{Au}, \mathrm{Pt}$ and Pd, bimetallic Au-Pt, Au-Pd, Pt-Bi, Pt-Sb, Pt-Cu, Pt-Co catalysts were compared and discussed.

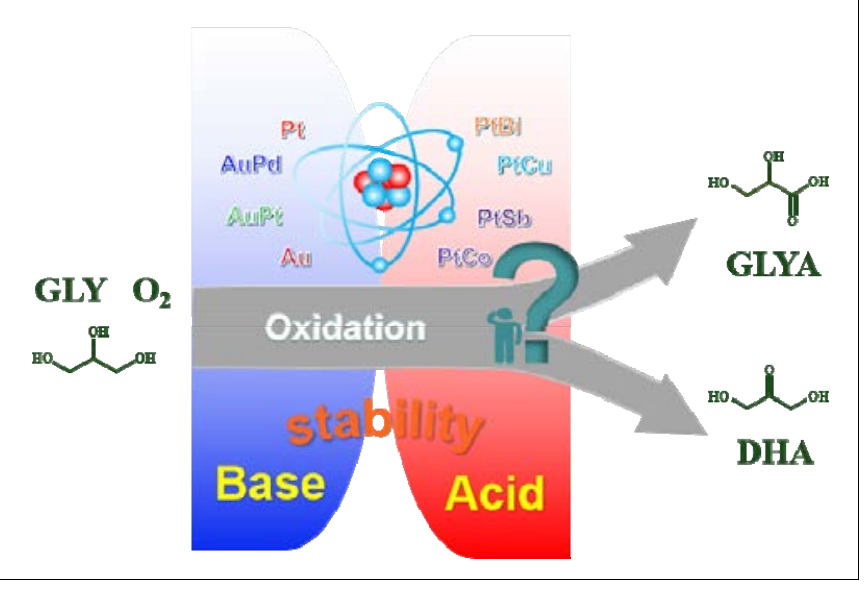


[15] OECD-FAO Agricultural Outlook 2016-2025, OECD Publishing: Paris, 2014, DOI:10.1787/agr_outlook-2016-en.

[16] P. S. Kong, M. K. Aroua, W. M. A. W. Daud, Renew. Sust. Energ. Rev., 2016, 63, 533-555.

[17] M. R. Nanda, Z. Yuan,W. Qin, H. S. Ghaziaskar, M. Poirier, C. Xu, Appl. Energy, 2014, 123, 75-81.

[18] J. N. Chheda, G. W. Huber, J. A. Dumesic, Angew. Chem. Int. Ed., 2007, 46, 7164-7183.

[19] C. Zhang, T. Wang, Y. J. Ding, Chin. J. Catal., 2017, 38, 928-937.

[20] M. L. Faroppa, J. J. Musci, M. E. Chiosso, C. G. Caggiano, H. P. Bideberripe, J. L. G. Fierro, G. J. Siri, M. L. Casella, Chin. J. Catal., 2016, 37, 1982-1990.

[21] J. Y. Cai, H. Ma, J. J. Zhang, Z. T. Du, Y. Z. Huang, J. Gao, J. Xu, Chin. J. Catal., 2014, 35, 1653-1660.

[22] T. Jedsukontorn, V. Meeyoo, N. Saito, M. Hunsom, Chin. J. Catal., 2016, 37, 1975-1981.

[23] G. Dodekatos, L. Abis, S. J. Freakley, H. Tüysüz, G. J. Hutchings, ChemCatChem, 2018, 10, 1351-1359.

[24] C. J. Yang, F. Zhang, N. Lei, M.Yang, F. Liu, Z. L. Miao, Y. N. Sun, X. C. Zhao, A. Q. Wang, Chin. J. Catal., 2018, 39, 1366-1372.

[25] M. Yang, X. C. Zhao, Y. J. Ren, J. Wang, N. Lei, A. Q. Wang, T. Zhang, Chin. J. Catal., 2018, 39, 1027-1037.

[26] C. Li, B. He, Y. Ling, C. W. Tsang, C. H. Liang, Chin. J. Catal., 2018, 39, 1121-1128.

[27] A. Talebian-Kiakalaieh, N. Aishah, S. Amin, Chin. J. Catal., 2017, 38, 1697-1710.

[28] H. Y. Du, S. Chen, H. W. Wang, J. L. Lu, Chin. J. Catal., 2017, 38, 1237-1244.

[29] W. T. Luo, Y. Lyu, L. F. Gong, H. Du, M. Jiang, Y. J. Ding, Chin. J. Catal., 2016, 37, 2009-2017.

[30] D. F. Li, W. X. Ni, Z. S. Hou, Chin. J. Catal., 2017, 38, 1784-1793.

[31] W. H. Yu, P. P. Wang, C. H. Zhou, H. B. Zhao, D. S. Tong, H. Zhang, H. M. Yang, S. F. Ji, H. Wang, Chin. J. Catal., 2017, 38, 1087-1100.

[32] H. M. Gan, X. G. Zhao, B. N. Song, L. Guo, R. Zhang, C. Chen, J. Z. Chen, W. W. Zhu, Z. S. Hou, Chin. J. Catal., 2014, 35, 1148-1156.

[33] M. Popova, H. Lazarova, Y. Kalvachev, T. Todorova, Á. Szegedi, P. Shestakova, G. Mali, V. D. B. C. Dasireddy, B. Likozar, Catal. Commun., 2017, 100, 10-14.

[34] J. L. Hu, J. J. Li, Y. L. Gu, Z. H. Guan, W. L. Mo, Y. M. Ni, T. Li, G. X. Li, Appl. Catal. A, 2010, 386, 188-193.

[35] L. P. Zheng, S. X. Xia, X. Y. Lu, Z. Y. Hou, Chin. J. Catal., 2015, 36, 1759-1765.

[36] S. Y. Pan. L. P. Zheng, R. F. Nie, S. X. Xia, P. Chen, Z. Y. Hou, Chin. J. Catal., 2012, 33, 1772-1777.

[37] A. Behr, J. Eilting, K. Irawadi, J. Leschinski, F. Lindner, Green Chem., 2008, 10, 13-30.

[38] D. L. Sun, Y. Yamada, S. Sato, W. Ueda, Green Chem., 2017, 19, 3186-3213.

[39] M. Pagliaro, R. Ciriminna, H. Kimura, M. Rossi, C. D. Pina, Angew. Chem. Int. Ed., 2007, 46, 4434-4440.

[40] M. S. Ide, R, J. Davis, Acc. Chem. Res., 2014, 47, 825-833.

[41] A. Villa, N. Dimitratos, C. E. Chan-Thaw, C. Hammond, L. Prati, G. J. Hutchings, Acc. Chem. Res., 2015, 48, 1403-1412.

[42] G. Dodekatos, S. Schünemann, H. Tüysüz, ACS Catal., 2018, 8, 6301-6333.

[43] Y. Nakagawa, K. Tomishige, Catal. Sci. Technol., 2011, 1, 179-190.

[44] Y. L. Wang, J. X. Zhou, X. W. Guo, RSC Adv., 2015, 5, 74611-74628.

[45] D. Sun, Y. Yamada, S. Sato, W. Ueda, Appl. Catal. B, 2016, 193, 75-92.

[46] B. Katryniok, S. Paul, F. Dumeignil, ACS Catal., 2013, 3, 1819-1834.

[47] A. E. Diaz-Alvarez, J. Francos, B. Lastra-Barreira, P. Crochet, V.
Cadierno, Chem. Commun., 2011, 47, 6208-6227.

[48] R. Wessendorf, Erdoel Kohle Erdgas Petrochem., 1995, 48, 138-143.

[49] J. M. Clacens, Y. Pouilloux and J. Barrault, Appl. Catal. A, 2002, 227, 181-190.

[50] H. Kunieda, A. Akahanem, J. Feng, M. Ishitobi, J. Colloid Interface Sci., 2002, 245, 365-370.

[51] K. A. Oudhoff, F. A. VanDamme, E. P. C. Mes, P. J. Schoenmakers, W. T. Kok, J. Chromatogr. A, 2004, 1046, 263-269.

[52] J. X. Liu, Y. M. Li, H. M. Liu, D. H. He, Biomass Bioenergy, 2018, 118, 74-83.

[53] H. Kimura, K. Tsuto, T. Wakisaka, Y. Kazumi, Y. Inaya, Appl. Catal. A, 1993, 96, 217-228.

[54] R. Garcia, M. Besson, P. Gallezot, Appl. Catal. A, 1995, 127, 165-176.

[55] S. Carrettin, P. McMorn, P. Johnston, K. Griffin, G. J. Hutchings, Chem. Commun., 2002, 696-697.

[56] S. Carrettin, P. McMorn, P. Johnston, K. Griffin, C. J. Kielyc, G. J. Hutchings, Phys. Chem. Chem. Phys., 2003, 5, 1329-1336.

[57] S. Carrettin, P. McMorn, P. Johnston, K. Griffin, C. Kiely, G. Attard, G. Hutchings, Top. Catal., 2004, 27, 131-136.

[58] F. Porta, L. Prati, J. Catal., 2004, 224, 397-403.

[59] N. Dimitratos, J. A. Lopez-Sanchez, D. Lennon, F. Porta, L. Prati, A. Villa, Catal. Lett., 2006, 108, 147-153.

[60] W. C. Ketchie, Y. L. Fang, M. S. Wong, M. Murayama, R. J. Davis, J. Catal., 2007, 250, 94-101.

[61] S. Demirel-Gulen, M. Lucas, P. Claus, Catal. Today, 2005, 102-103, 166-172.

[62] C. L. Bianchi, P. Canton, N. Dimitratos, F. Porta, L. Prati, Catal. Today, 2005, 102-103, 203-212.

[63] D. Wang, A. Villa, F. Porta, D. Su, L. Prati, Chem. Commun., 2006, 1956-1958.

[64] W. C. Ketchie, M. Murayama, R. J. Davis, J. Catal., 2007, 250, 264-273.

[65] S. Demirel, K. Lehnert, M. Lucas, P. Claus, Appl. Catal. B, 2007, 70, 637-643.

[66] R. Bauer, D. Hekmat, Biotechnol Prog., 2010, 22, 278-284.

[67] S. S. Liu, K. Q. Sun, B. Q. Xu, ACS Catal., 2014, 4, 2226-2230.

[68] Z. F. Yuan, Z. K. Gao, B. Q. Xu, Chin. J. Catal., 2015, 36, 1543-1551.

[69] J. Gao, D. Liang, P. Chen, Z. Y. Hou, X. M. Zheng, Catal. Lett., 2009, 130, 185-191.

[70] D. Liang, J. Gao, J. Wang, P. Chen, Z. Hou, X. Zheng, Catal. Commun., 2009, 10, 1586-1590.

[71] B. N. Zope, D. D. Hibbits, M. Neurock, R. J. Davis, Science, 2010, 330, 74-78.

[72] D. Liang, J. Gao, H. Sun, P. Chen, Z. Y. Hou, X. M. Zheng, Appl. Catal. $B, \mathbf{2 0 1 1}, 106,423-432$.

[73] M. Y. Zhang, R. F. Nie, L. N. Wang, J. J. Shi, W. C. Du, Z. Y. Hou, Catal. Commun., 2015, 59, 5-9.

[74] J. Q. Lei, X. Z. Duan, G. Qian, X. G. Zhou, D. Chen, Ind. Eng. Chem. Res., 2014, 53, 16309-16315.

[75] Y. Li, F. Zaera. J. Catal., 2015, 326, 116-126.

[76] H. Tan, O. E. Tall, Z. H. Liu, N. Wei, T. Yapici, T. Zhan, M. N. Hedhill, Y. Han, ChemCatChem, 2016, 8, 1699-1707.

[77] M. S. Ide, D. D. Falcone, R. J. Davis, J. Catal., 2014, 311, 295-305.

[78] Y. Y. Sun, X. W. Li, J. G. Wang, W. S. Ning, J. Fu, X. Y. Lu, Z. Y. Hou, Appl. Catal. B, 2017, 218, 538-544.

[79] S. S. Chen, P. Y. Qi, J. Chen, Y. Z. Yuan, RSC Adv., 2015, 5, 31566-31574.

[80] X. M. Ning, H. Yu, F. Peng, H. J. Wang, J. Catal., 2015, 325, 136-144.

[81] X. M. Ning, Y. H. Li, B. Q. Dong, H. J. Wang, H. Yu, F. Peng, Y. H. Yang, J. Catal., 2017, 348, 100-109. 
[82] F. F. Wang, S. Shao, C. L. Liu, C. L. Xu, R. Z. Yang, W. S. Dong, Chem. Eng. J., 2015, 264, 336-343.

[83] D. H. Guo, R. Shibuya, C. Akiba, S. Saji, T. Kondo, J. Nakamura, Science, 2016, 351, 361-365.

[84] M. Y. Zhang, J. J. Shi, Y. Y. Sun, W. S. Ning, Z. Y. Hou, Catal. Commun., 2015, 70, 72-76.

[85] L. H. Yang, X. W. Li, Y. Y. Sun, L. H. Yue, J. Fu, X. Y. Lu, Z. Y. Hou, Catal. Commun., 2017, 101, 107-110.

[86] M. Y. Zhang, Y. Y. Sun, J. J. Shi, W. S. Ning, Z. Y. Hou, Chin. J. Catal., 2017, 38, 537-544.

[87] M. Sankar, N. Dimitratos, P. J. Miedziak, P. P. Wells, C. J. Kiely, G. J. Hutchings, Chem. Soc. Rev., 2012, 41, 8099-8139.

[88] T. Otto, J. M. Ramallo-López, L. J. Giovanetti, F. G. Requejo, S. I. Zones, E. Iglesia, J. Catal., 2016, 342, 125-137.

[89] A. Villa, G. M. Veith, L. Prati, Angew. Chem. Int. Ed., 2010, 49, 4499-4502.

[90] N. Dimitratos, C. Messi, F. Porta, L. Prati, A. Villa, J. Mol. Catal. A, 2006, 256, 21-28.

[91] B. S. Sánchez, M. S. Gross, C. A. Querini, Catal. Today, 2017, 296, $35-42$.

[92] G. L. Brett, Q. He, C. Hammond, P. J. Miedziak, N. Dimitratos, M. Sankar, A. A. Herzing, M. Conte, J. A. Lopez-Sanchez, C. J. Kiely, D. W. Knight, S. H. Taylor, G. J. Hutchings, Angew. Chem. Int. Ed., 2011, 50, 10136-10139.

[93] D. Tongsakul, S. Nishimura, K. Ebitani, ACS Catal., 2013, 3, 2199-2207.

[94] D. Roy, B. Subramaniam, R. V. Chaudhari, ACS Catal., 2011, 1, 548-551.

[95] D. Liang, J. Gao, J. H. Wang, P. Chen, Y. F. Wei, Z. Y. Hou, Catal. Commun., 2011, 12, 1059-1062.

[96] M. Y. Zhang, J. J. Shi, W. S. Ning, Z. Y. Hou, Catal. Today, 2017, 298, 234-240.

[97] J. Dou, B. Zhang, H. Liu, J. D. Hong, S. M. Yin, Y. Z. Huang, Appl. Catal. B, 2016, 180, 78-85.

[98] S. A. Kondrat, P. J. Miedziak, M. Douthwaite, G. L. Brett, T. E. Davies, D. J. Morgan. J. K. Edwards, D. W. Knight, C. J. Kiely, S. H. Taylor, G. J. Hutchings, ChemSusChem, 2014, 7, 1326-1334.

[99] A Villa, S. Campisi, K. M. H. Mohammed, N. Dimitratos, F. Vindigni, M.Manzoli, W. Jones, M. Bowker, G. J. Hutchings, L. Prati, Catal. Sci. Technol., 2015, 5, 1126-1132.

[100] C. L. Xu, Y. Q. Du , C. Li , J. Yang, G. Yang, Appl. Catal. B, 2015, 164, 334-343.

[101] A. Brandner, K. Lehnert, A. Bienholz, M. Lucas, P. Claus, Top. Catal., 2009, 52, 278-287.

[102] H. Kimura, K. Tsuto, T. Wakisaka, Y. Kazumi, Y. Inaya, Appl. Catal. A, 1993, 105, 147-158.
[103] C. Mondelli, D. Ferri, J. Grunwaldt, F. Krumeich, S. Mangold, R. Psaro, A. Baiker, J. Catal., 2007, 252, 77-87.

[104] Y. Kwon, Y. Birdja, I. Spanos, P. Rodriguez, M.T.M. Koper, ACS Catal., 2012, 2, 759-764.

[105] M. Wenkin, P. Ruiz, B. Delmon, M. Devillers, J. Mol. Catal. A, 2002, 180, 141-159.

[106] A. Abbadi, H. van Bekkum, Appl. Catal. A, 1995, 124, 409-417.

[107] R. F. Nie, D. Liang, L. Shen, J. Gao, P. Chen, Z. Y. Hou, Appl. Catal. B, 2012, 127, 212-220.

[108] H. H. Li, S. Zhao, M. Gong, C. H. Cui, D. He, H. W. Liang, L. Wu, S. H. $\mathrm{Yu}$, Angew. Chem. Int. Ed., 2013, 52, 7472-7476.

[109] A. V. Tripkovic, K. D. Popovic, R. M. Stevanovic, R. Socha, A. Kowal, Electrochem. Commun., 2006, 8, 1492-1498.

[110] T. Mallat, Z. Bodnar, A. Baiker, O. Greis, H. Strubig, A. Reller, J. Catal., 1993, 142, 237-253.

[111] M. M. Tusi, N. S. O. Polanco, S. G. da Silva, E. V. Spinacé, A. O. Neto, Electrochem. Commun., 2011, 13, 143-146.

[112] D. Liang, S. Y. Cui, J. Gao, J. H. Wang, P. Chen, Z. Y. Hou, Chin, J. Catal., 2011, 32, 1831-1837.

[113] X. M. Ning, Y. H. Li, H. Yu, F. Peng, H. J. Wang, Y. H. Yang, J. Catal., 2016, 335, 95-104.

[114] Y. Xiao, Z. J. Zhao, J. Greeley, G. M. Xiao, A. Varma, AIChE J., 2017, 63, 705-715.

[115] W. Hu, D. Knight, B. Lowry, A. Varma, Ind. Eng. Chem. Res., 2010, 49, 10876-10882.

[116] N. Worz, A. Brandner, P. Claus, J. Phys. Chem. C, 2010, 114, 1164-1172.

[117] W. B. Hu, B. Lowry, A. Varma, Appl. Catal. B, 2011, 106, 123-132.

[118] N. Mimura, N. Hiyoshi, T. Fujitani, F. Dumeignil, RSC Adv., 2014, 4, 33416-33423.

[119] N. Mimura, N. Muramatsu, N. Hiyoshi, O. Sato, Y. Masuda, A. Yamaguchi, ACS Omega, 2018, 3, 13862-13868.

[120] D. Motta, F. J. S. Trujillo, N. Dimitratos, A. Villa, L. Prati, Catal. Today, 2018, 308, 50-57.

[121] G. M. Lari, C. Mondelli, J. Peŕez-Ramıŕez, ACS Catal., 2015, 5, 1453-1461.

[122] J. Im, M. Choi, ACS Catal., 2016, 6, 2819-2826.

[123] M. H. Wiebenga, C. H. Kim, S. J. Schmieg, S. H. Oh, D. B. Brown, D. H. Kim, J. H. Lee, C. H. F. Peden, Catal. Today, 2012, 184, 197-204.

[124] H. A. Rass, N. Essayem, M. Besson, Green Chem., 2013, 15, 2240-2251.

[125] C. Mondelli, J. D. Grunwaldt, D. Ferri, A. Baiker, Phys. Chem. Chem. Phys., 2010, 12, 5307-5316.

[126] B. N. Zope, R. J. Davis, Green Chem., 2011, 13, 3484-3491.

[127] M. S. Ide, R. J. Davis, J. Catal., 2013, 308, 50-59.

\section{无碱溶液中的甘油选择性氧化：简短的综述

\author{
杨丽华 ${ }^{\mathrm{a}}$, 黎学文 ${ }^{\mathrm{a}}$, 陈 平 ${ }^{\mathrm{a}}$, 侯昭胤, ${ }^{\mathrm{a}, \mathrm{b}}$ * \\ a浙江大学化学系生物质化工教育部重点实验室, 浙江杭州310028

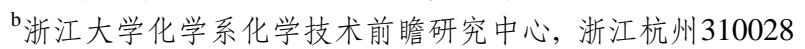

摘要: 生物柴油是一种重要的“绿色能源”, 它燃烧性能好, 生产原料来源广泛, 可再生, 已经成为欧美等国广泛使用的绿色 燃料. 但是, 采用甘油三酯通过酯交换生产生物柴油的同时, 甘油作为副产物也大量生成. 据统计, 2015年全球生物柴油基 甘油的产量已经超过350万吨, 因此将过剩的甘油转化为其他更有价值的化学品具有重要意义. 本文首先介绍了目前文献 中广泛报道的甘油转化工艺, 如氧化、氢解、脱水、酯化、醚化、酯交换、聚合等及上述反应可以制备的一系列化学品, 然 后结合我们课题组的研究进展, 详细论述了甘油选择氧化的催化剂和反应工艺.

采用分子氧作为氧化剂, 在固体催化剂作用下, 甘油可以氧化成二美基丙酮、甘油酸、甘油醛等具有高附加值的精细 
化学品. 在发表的文献中, 单一的Pt, Pd, Au催化剂, 以及多组分的Au-Pt, Au-Pd, Pt-Bi, Pt-Cu, Pt-Sb, Pt-Co催化剂等在液相 甘油氧化反应中的活性规律及构效关系已经被广泛报道.

早期的研究结果普遍认为, 碱性助剂在甘油氧化反应中起着举足轻重的作用, 这是因为反应溶液中的 $\mathrm{OH}^{-}$可以促进甘 油的初始脱氢, 是开启氧化过程的必要步骤. 但是, 碱的加入会导致产物以盐的形式存在, 必须通过进一步的分离和中和 才能得到最终产物, 这些步骤有可能在数据分析和机理研究中带来误差. 因此, 在无碱溶液下进行甘油氧化并得到较高的 甘油转化率和目的产物选择性具有重要意义.

近几年来, 有关在酸性溶液中(不添加碱性助剂)将甘油高效氧化的催化剂及其反应机理的研究得到了广泛认可和快速 发展. 本文详细介绍了单一的 $\mathrm{Pt}$ 催化剂以及 $\mathrm{Au}, \mathrm{Cu}, \mathrm{Pd}, \mathrm{Co}$ 等改进的 $\mathrm{Pt}$ 催化剂在甘油氧化制备甘油酸反应中的活性规律和 构效关系, 讨论了金属形貌、载体的组成和结构、反应条件等的影响以及甘油氧化反应机理等. 同时, 本文还特别涉及在 甘油氧化制二差基丙酮反应中一些双金属催化剂(如Pt-Bi和Pt-Sb)的特殊结构和作用机理, 对比了助剂与Pt的结合模式(如 site-block和合金)及其与甘油活化、中间产物转化之间的关系. 依据上述文献并结合最新 $\mathrm{Au} / \mathrm{CuO}$ 催化剂活性规律的研究进 展, 我们认为二羟基丙酮是甘油氧化的初始产物, 但由于二羟基丙酮很不稳定, 极易进一步氧化成甘油酸及其它深度氧化 产物, 因此Pt-Bi和Pt-Sb催化剂中Bi和Sb等助剂的主要作用可归结为抑止二羟基丙酮的进一步氧化.

最后, 本文介绍了最近报道的在固定床反应器中进行的甘油连续氧化反应的催化剂及其活性规律. 关键词: 甘油; 氧化; 无碱条件; 催化剂; 反应机理

收稿日期: 2018-11-18. 接受日期: 2019-01-09. 出版日期: 2019-07-05.

*通讯联系人. 电话/传真: (0571)88273283; 电子信箱: zyhou@zju.edu.cn

基金来源：国家自然科学基金(21773208, 21473155); 浙江省自然科学基金(L12B03001).

本文的电子版全文由Elsevier出版社在ScienceDirect上出版(http://www.sciencedirect.com/science/journal/18722067). 